University of Nebraska - Lincoln

DigitalCommons@University of Nebraska - Lincoln

2008

\title{
Hydrogenase- and outer membrane c-type cytochrome-facilitated reduction of technetium(VII) by Shewanella oneidensis MR-1
}

\author{
Matthew J. Marshall \\ Pacific Northwest National Laboratory \\ Andrew Plymale \\ Pacific Northwest National Laboratory, andrew.plymale@pnl.gov \\ David W. Kennedy \\ Pacific Northwest National Laboratory \\ Liang Shi \\ Pacific Northwest National Laboratory, liang.shi@pnl.gov \\ Zheming Wang \\ Pacific Northwest National Laboratory \\ See next page for additional authors
}

Follow this and additional works at: https://digitalcommons.unl.edu/usdoepub

Part of the Bioresource and Agricultural Engineering Commons

Marshall, Matthew J.; Plymale, Andrew; Kennedy, David W.; Shi, Liang; Wang, Zheming; Reed, Samantha B.; Dohnalkova, Alice; Simonson, Cody; Liu, Chongxuan; Saffarini, Daad A.; Romine, Margaret F.; Zachara, John M.; Beliaev, Alexander S.; and Fredrickson, James K., "Hydrogenase- and outer membrane c-type cytochrome-facilitated reduction of technetium(VII) by Shewanella oneidensis MR-1" (2008). US Department of Energy Publications. 199.

https://digitalcommons.unl.edu/usdoepub/199

This Article is brought to you for free and open access by the U.S. Department of Energy at DigitalCommons@University of Nebraska - Lincoln. It has been accepted for inclusion in US Department of Energy Publications by an authorized administrator of DigitalCommons@University of Nebraska - Lincoln. 


\section{Authors}

Matthew J. Marshall, Andrew Plymale, David W. Kennedy, Liang Shi, Zheming Wang, Samantha B. Reed, Alice Dohnalkova, Cody Simonson, Chongxuan Liu, Daad A. Saffarini, Margaret F. Romine, John M.

Zachara, Alexander S. Beliaev, and James K. Fredrickson 


\section{Hydrogenase- and outer membrane c-type cytochrome-facilitated reduction of technetium(VII) by Shewanella oneidensis MR-1}

Matthew J. Marshall, ${ }^{1 *}$ Andrew E. Plymale, ${ }^{1}$

David W. Kennedy, ${ }^{1}$ Liang Shi, ${ }^{1}$ Zheming Wang, ${ }^{2}$

Samantha B. Reed, ${ }^{1}$ Alice C. Dohnalkova, ${ }^{1}$

Cody J. Simonson, ${ }^{1}$ Chongxuan Liu, ${ }^{2}$

Daad A. Saffarini, ${ }^{3}$ Margaret F. Romine, ${ }^{1}$

John M. Zachara, ${ }^{2}$ Alexander S. Beliaev ${ }^{1}$ and

James K. Fredrickson ${ }^{1}$

${ }^{1}$ Biological Sciences Division and ${ }^{2}$ Chemical and

Material Sciences Division, Pacific Northwest National

Laboratory, Richland, WA 99354, USA.

${ }^{3}$ Department of Biological Sciences, University of

Wisconsin, Milwaukee, WI 53211, USA.

\section{Summary}

Pertechnetate, ${ }^{99} \mathrm{Tc}(\mathrm{VII}) \mathrm{O}_{4}^{-}$, is a highly mobile radionuclide contaminant at US Department of Energy sites that can be enzymatically reduced by a range of anaerobic and facultatively anaerobic microorganisms, including Shewanella oneidensis MR-1, to poorly soluble $\mathrm{Tc}(\mathrm{IV}) \mathrm{O}_{2(\mathrm{~s})}$. In other microorganisms, $\mathrm{Tc}(\mathrm{VII}) \mathrm{O}_{4}{ }^{-}$reduction is generally considered to be catalysed by hydrogenase. Here, we provide evidence that although the NiFe hydrogenase of MR-1 was involved in the $\mathrm{H}_{2}$-driven reduction of $\mathrm{Tc}(\mathrm{VII}) \mathrm{O}_{4}{ }^{-}$ [presumably through a direct coupling of $\mathrm{H}_{2}$ oxidation and $\mathrm{Tc}$ (VII) reduction], the deletion of both hydrogenase genes did not completely eliminate the ability of MR-1 to reduce Tc(VII). With lactate as the electron donor, mutants lacking the outer membrane $c$-type cytochromes MtrC and OmcA or the proteins required for the maturation of $c$-type cytochromes were defective in reducing $\mathrm{Tc}(\mathrm{VII})$ to nanoparticulate $\mathrm{TcO}_{2} \cdot \mathrm{nH}_{2} \mathrm{O}_{\text {(s) }}$ relative to MR-1 or a NiFe hydrogenase mutant. In addition, reduced MtrC and OmcA were oxidized by $\mathrm{Tc}(\mathrm{VII}) \mathrm{O}_{4}^{-}$, confirming the capacity for direct electron transfer from these OMCs to $\mathrm{TcO}_{4}^{-}$. $c$-Type cytochrome-catalysed $\mathrm{Tc}(\mathrm{VII})$ reduction could be a potentially important mechanism in environments where organic electron donor concentrations are sufficient to allow this reaction to dominate.

Received 13 June, 2007; accepted 11 August, 2007. *For correspondence. E-mail matthew.marshall@pnl.gov; Tel. (+1) 509 376 1921; Fax (+1) 5093761443.

\section{Introduction}

At several US Department of Energy (US DOE) sites, ${ }^{99}$ technetium, a by-product of the nuclear fuel cycle, threatens to contaminate ground- and surface-water resources (Riley et al., 1992). Under oxidizing conditions in these environments, ${ }^{99} \mathrm{TC}$ is present as pertechnetate $\left[\mathrm{Tc}(\mathrm{VII}) \mathrm{O}_{4}^{-}\right]$, which is not strongly sorbed and considered highly mobile in the subsurface (Wildung et al., 2000). Environmental mobility is a major risk factor for Tc contamination at DOE's Hanford Site, where significant quantities are predicted to migrate in groundwater beneath the site to the Columbia River in the future. One strategy for containing the spread of Tc contamination has been to exploit the decreased solubility of Tc in the (IV) oxidation state. In the absence of strong complexing ligands, $\mathrm{Tc}(\mathrm{IV}) \mathrm{O}_{2(\mathrm{~s})}$ is poorly soluble $\left(\right.$ e.g. $\left.<10^{-8} \mathrm{~mol} \mathrm{I}^{-1}\right)$ and hence mobility in the environment is significantly lower. Therefore, the biotic reduction of $\mathrm{Tc}(\mathrm{VII})$ to $\mathrm{Tc}(\mathrm{IV}) \mathrm{O}_{2}$ by organisms such as Shewanella, Desulfovibrio and Geobacter could substantially limit the mobility of Tc contamination plumes (Lloyd and Macaskie, 1996; Lloyd et al., 1999a; 2000; Wildung et al., 2000).

Shewanella oneidensis MR-1 can reduce a variety of terminal electron acceptors including: $\mathrm{O}_{2}$, nitrate, fumarate, dimethylsulfoxide (DMSO), thiosulfate, trimethylamine oxide (TMAO), $\mathrm{S}^{0}, \mathrm{Fe}(\mathrm{III}), \mathrm{Mn}(\mathrm{III}, \mathrm{IV}), \mathrm{Cr}(\mathrm{VI})$, $\mathrm{Co}(\mathrm{III}), \mathrm{V}(\mathrm{V}), \mathrm{U}(\mathrm{VI})$ and $\mathrm{Tc}(\mathrm{VII})$ via the oxidation of lactate, formate or $\mathrm{H}_{2}$ and other electron donors (Myers and Nealson, 1988; 1990; Nealson and Saffarini, 1994; Lloyd and Macaskie, 1996; Liu et al., 2002; Carpentier et al., 2003). The annotated genomic sequence (Heidelberg et al., 2002) of S. oneidensis MR-1 revealed numerous genes predicted to encode putative redox proteins including cytochromes, hydrogenases, flavins, ferredoxins and Fe-S proteins. Genome comparisons with other sequenced dissimilatory metal-reducing bacteria (DMRB) such as Geobacter sulfurreducens, G. metallireducens (Lovley et al., 2004) and Anaeromyxobacter dehalogenans reveal that these organisms share a remarkable wealth of genes that encode one particular type of electron transfer protein, the multihaem $c$-type cytochrome. While the organisms display no significant sequence homology, the abundance of $c$-type cytochromes appears 
to be a common characteristic of DMRB and is likely linked to their considerable flexibility in electron acceptor utilization.

The diverse electron transport chain of $S$. oneidensis MR-1 features 42 putative $c$-type cytochromes (Meyer et al., 2004), some of which have recently been shown to function as terminal reductases of many substrates and to directly facilitate energy production (Beliaev et al., 2001; Myers and Myers, 2001; Marshall et al., 2006; Shi et al., 2006). In cell fractionation studies using anaerobically grown S. oneidensis MR-1, a large percentage of the membrane-bound $c$-type cytochromes were found to be associated with the outer membrane (OM) cell fractions (Myers and Myers, 1992). Importantly, some of these OM $c$-type cytochromes (OMCs) were localized on the outer face of the OM (Myers and Myers, 2003a) directly facilitating contact with both extracellular soluble and insoluble electron acceptors. Mutagenesis studies in S. oneidensis MR-1 identified a cluster of metal reduction-specific genes (Beliaev and Saffarini, 1998; Beliaev et al., 2001) including one that encodes a putative decahaem OMC, mtrC (locus tag: SO1778) (Beliaev et al., 2001). The gene encoding an additional decahaem $\mathrm{OMC}$ with a role in metal reduction, designated omcA (SO1779), was subsequently identified and characterized (Myers and Myers, 1998; 2003b). To date, the roles of MtrC and OmcA in electron transfer to metals have been the most extensively studied of the $c$-type cytochromes in S. oneidensis MR-1 (Beliaev et al., 2001; Myers and Myers, 2001; 2003a,b; Shi et al., 2006; Xiong et al., 2006; Wigginton et al., 2007). Both MtrC and OmcA have been shown to play a role in $\mathrm{U}(\mathrm{VI})$ reduction and subsequent subcellular localization of nanoparticulate uraninite, $\mathrm{U}(\mathrm{IV}) \mathrm{O}_{2}$, while in vitro assays demonstrated that reduced $\mathrm{MtrC}$ was also oxidized directly by $\mathrm{U}(\mathrm{VI})$, indicating that MtrC functioned as a terminal reductase of U(VI) (Marshall et al., 2006).

In addition to $c$-type cytochromes, hydrogenases comprise another class of enzymes that play a central role in microbial redox metabolism catalysing the bidirectional reaction of $\mathrm{H}_{2}$ oxidation with the formation of two protons and two electrons. In some non-DMRB, hydrogenases have been found to function as $\mathrm{Tc}(\mathrm{VII})$ reductases by coupling $\mathrm{H}_{2}$ oxidation and enzymatic $\mathrm{Tc}(\mathrm{VII})$ reduction (Lloyd and Macaskie, 1997; De Luca et al., 2001). However, among the DMRB the involvement of hydrogenase in the reduction of $\mathrm{Tc}(\mathrm{VII})$ has only been circumstantial based on either amino acid homologies to other hydrogenases (Wildung et al., 2000) or the exclusive requirement for $\mathrm{H}_{2}$ as the electron donor for direct Tc(VII) reduction (Lloyd et al., 2000). Two major groups of hydrogenases exist, NiFe hydrogenases and Fe-only hydrogenases, which are classified by the metal atoms associated with their active centre (Vignais et al., 2001; Vignais and Colbeau, 2004). The genome of $S$. oneidensis MR-1 encodes both an Fe-only hydrogenase hydAB (SO3920 and SO3921 respectively) and a NiFe hydrogenase hyaAB (SO2099 and SO2098 respectively), both of which are heterodimers composed of a large and small subunit (Heidelberg et al., 2002). Recently, the roles of these hydrogenases in $\mathrm{H}_{2}$ metabolism by MR-1 were characterized (Meshulam-Simon et al., 2007). The NiFe hydrogenase was found to be the predominant hydrogenase and functioned bidirectionally, both forming and releasing $\mathrm{H}_{2}$, while the Fe-only hydrogenase was found to be predominantly involved in $\mathrm{H}_{2}$ formation. This study also confirmed that these two gene loci encode the only hydrogenases in MR-1. Cross-genome comparisons and sequence alignment revealed conservation of the NiFe hydrogenase (HyaAB) among most sequenced Shewanella strains, while few homologues of the Fe-only hydrogenase (HydAB) exist in other Shewanella isolates (http:// genome.jgi-psf.org/mic_home.html).

The purpose of this study was to determine the mechanism(s) involved in the reduction of $\mathrm{Tc}(\mathrm{VII}) \mathrm{O}_{4}^{-}$by S. oneidensis MR-1. To date, c-type cytochromes have not been shown to have a role in $\mathrm{Tc}(\mathrm{VII})$ reduction. The putative role of hydrogenases in the reduction of $\mathrm{Tc}(\mathrm{VII})$ has only been predicted using homology to the hydrogenases of other organisms. To better understand the biochemical mechanisms of $\mathrm{Tc}(\mathrm{VII})$ reduction in MR-1, we tested several mutants lacking either $c$-type cytochromes or functional hydrogenases and evaluated their ability to reduce $\mathrm{Tc}(\mathrm{VII})$ compared with wild-type MR-1 using multiple electron donors. We compared the subcellular localizations of $\mathrm{TcO}_{2}$ nanoparticles in wild-type MR-1 with a mutant that reduced $\mathrm{Tc}(\mathrm{VII})$ at a significantly slower rate. Additionally, we tested purified OMCs for their ability to function as terminal reductases of $\mathrm{Tc}(\mathrm{VII})$ in a defined system. Hydrogenase mutants were also characterized for their donor-specific ability to transfer electrons to several other metals.

\section{Results}

The role of the NiFe and Fe-only hydrogenases in Tc(VII) reduction

To ascertain if either of the two predicted hydrogenases in $S$. oneidensis MR-1 were involved in $\mathrm{H}_{2}$ oxidation linked to $\mathrm{Tc}(\mathrm{VII})$ reduction, a series of in-frame deletion mutants were constructed. Mutants in genes encoding the large subunit of either the Fe-only hydrogenase, hydA (SO3920), or the NiFe hydrogenase, hyaB (SO2098), were generated by double homologous recombination (Table 1). A third mutant consisting of deletions of both the hyd $A$ and hyaB genes was also produced (Table 1). The reduction of $\mathrm{Tc}(\mathrm{VII})$ in the presence of either $\mathrm{H}_{2}$ (Fig. 1) or lactate (Fig. 2) as the sole electron donor was evaluated 
Table 1. Bacterial strains and plasmids used for this study.

\begin{tabular}{|c|c|c|}
\hline Strains and plasmids & Description & Reference \\
\hline \multicolumn{3}{|l|}{ Shewanella oneidensis } \\
\hline MR-1 & Manganese-reducing strain (Lake Oneida, NY) & Myers and Nealson (1988) \\
\hline $\mathrm{HydA}^{-}$ & $\begin{array}{l}\Delta S O 3920\left(h y d A^{-}\right) \text {deletion derivative of MR-1. } \\
\text { Also referred to as the Fe-only hydrogenase mutant }\end{array}$ & This work \\
\hline HyaB $^{-}$ & $\begin{array}{l}\Delta \mathrm{SO} 2098\left(h y a B^{-}\right) \text {deletion derivative of MR-1. } \\
\text { Also referred to as the NiFe hydrogenase mutant }\end{array}$ & This work \\
\hline CymA $^{-}$ & $\Delta \mathrm{SO} 4591\left(\right.$ cym $\left.A^{-}\right)$deletion derivative of MR-1 & This work \\
\hline $\mathrm{HydA}^{-} / \mathrm{HyaB}^{-}$ & Double-deletion derivative of $\Delta \mathrm{SO} 3920\left(h y d A^{-}\right)$and $\Delta \mathrm{SO} 2098$ (hyaB $)$ within MR-1 & This work \\
\hline $\mathrm{MtrC}^{-} / \mathrm{OmcA}^{-}$ & Double-deletion derivative of $\Delta \mathrm{SO} 1778\left(\mathrm{mtr}^{-}\right)$and $\Delta \mathrm{SO} 1779\left(\mathrm{omc} A^{-}\right)$within MR-1 & Marshall et al. (2006) \\
\hline $\mathrm{CcmC}^{-}$ & $\begin{array}{l}\text { pMiniHimar RB1 transposon insertion in SO0261 (ccmC) gene of MR-1. Requires } \\
\text { kanamycin }\left(50 \mu \mathrm{gl}^{-1}\right) \text { selection. } \\
\text { Also referred to as BG148 }\end{array}$ & Bouhenni et al. (2005) \\
\hline MenD- & $\begin{array}{l}\text { pMiniHimar RB1 transposon insertion in SO4573 }(\operatorname{menD}) \text { gene of MR-1. } \\
\text { Requires kanamycin }\left(50 \mu \mathrm{g} \mathrm{ml}^{-1}\right) \text { selection }\end{array}$ & This work \\
\hline HyaB- $^{-}(+p C R 4-h y a B)$ & $\begin{array}{l}\text { NiFe hydrogenase mutant }\left(\mathrm{HyaB}^{-}\right) \text {containing the complementation plasmid, } \\
\text { pCR4-hyaB }\end{array}$ & This work \\
\hline \multicolumn{3}{|c|}{ 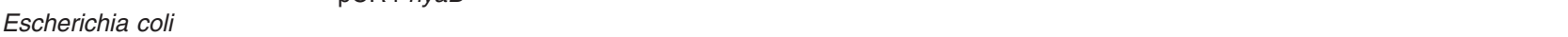 } \\
\hline EC100D pir-116 & $\begin{array}{l}\text { Host used for construction of pDS3.1 clones. } \\
\text { F- mcrA } \Delta(m r r-h s d R M S \text { mcrBC) } \phi 80 \mathrm{~d} / a c Z \Delta \mathrm{M} 15 \Delta / a c X 74 \text { recA1 endA1 araD139 } \\
\quad \Delta(\text { ara, leu }) 7697 \text { galU galK I- rpsL nupG pir-116 }\end{array}$ & Epicentre \\
\hline B2155 $\lambda$ pir & 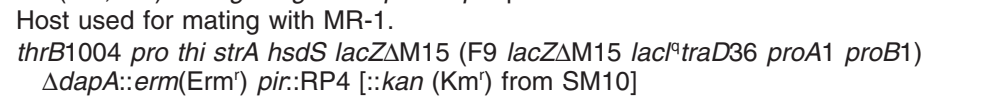 & Dehio and Meyer (1997) \\
\hline Top10 & 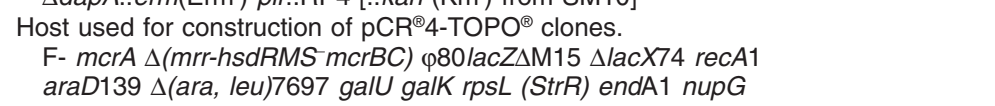 & Invitrogen \\
\hline \multicolumn{3}{|c|}{ che } \\
\hline pDS3.1 & Suicide vector, $\mathrm{Amp}^{r}, \mathrm{Gm}^{r}, \mathrm{sacB}^{+}$ & Wan et al. (2004) \\
\hline pDS3.1::hydA $A^{-}$ & pDS3.1 containing sequences that flank $h y d A$ & This work \\
\hline pDS3.1::hyaB- & pDS3. 1 containing sequences that flank $h y a B$ & This work \\
\hline pDS3.1::cymA- & pDS3. 1 containing sequences that flank cymA & This work \\
\hline $\mathrm{pCR}^{\circledR} 4-\mathrm{TOPO}^{\circledR}$ & Used for complementation of deletions in MR-1 Ampr ${ }^{r}, \mathrm{Kan}^{r}$ & Invitrogen \\
\hline pCR4-hyaB & $\begin{array}{l}\text { Used for complementation of the NiFe hydrogenase mutant }\left(\mathrm{HyaB}^{-}\right) \text {. } \\
\text { pCR }^{\circledR} 4-\mathrm{TOPO}^{\circledR} \text { containing native hyaB downstream to lac promoter }\end{array}$ & This work \\
\hline
\end{tabular}

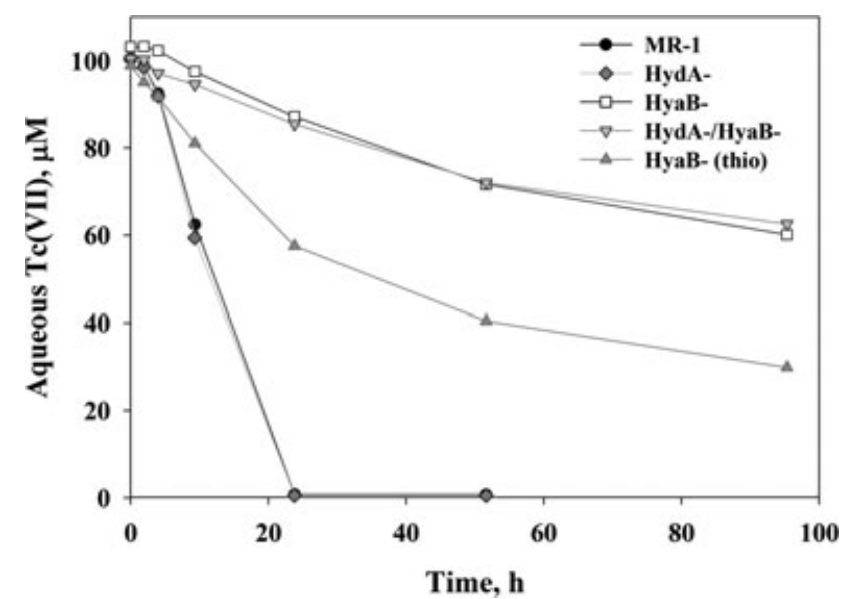

Fig. 1. $\mathrm{H}_{2}$-driven $\mathrm{Tc}(\mathrm{VII})$ reduction kinetics by $\mathrm{S}$. oneidensis $\mathrm{MR}-1$ and hydrogenase mutant cells. The reduction of $100 \mu \mathrm{M} \mathrm{Tc}(\mathrm{VII})$ was determined for MR-1, single-hydrogenase deletion mutants $\left(\mathrm{HydA}^{-}\right.$or $\left.\mathrm{HyaB}^{-}\right)$, a double-hydrogenase deletion mutant $\left(\mathrm{HydA} \mathrm{A}^{-} / \mathrm{HyaB}^{-}\right)$or NiFe hydrogenase mutant cells induced with thiosulfate $\left[\mathrm{HyaB}^{-}\right.$(thio)] using $10 \mathrm{ml}$ of $\mathrm{H}_{2}$ as the electron donor.

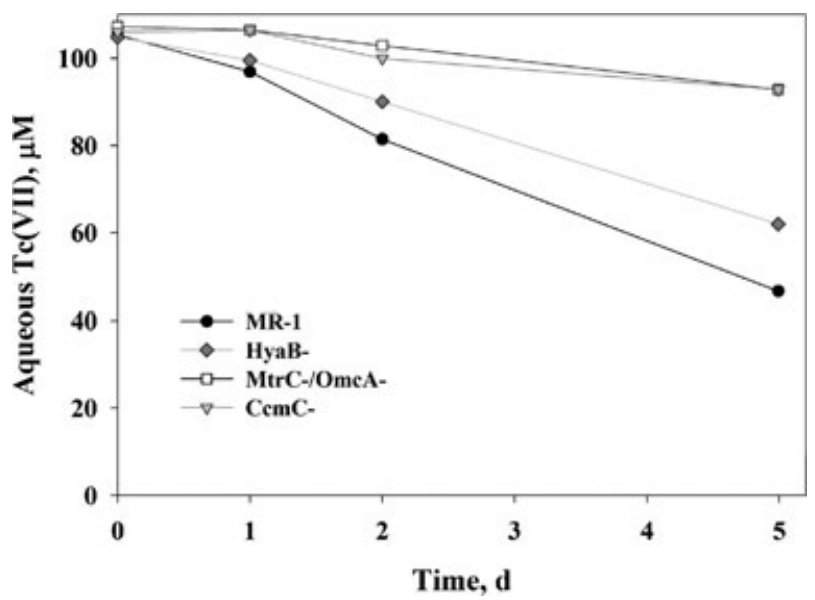

Fig. 2. Tc(VII) reduction kinetics by $S$. oneidensis MR-1 and hydrogenase or $c$-type cytochrome mutant cells using lactate as the sole electron donor. The reduction of $100 \mu \mathrm{M} \mathrm{Tc}(\mathrm{VII})$ was determined for MR-1, a deletion of the NiFe hydrogenase (HyaB-), a mutant lacking all $c$-type cytochromes $\left(\mathrm{CcmC}^{-}\right)$and a double-OMC deletion mutant ( $\mathrm{MtrC}^{-} / \mathrm{OmcA}^{-}$) using $5 \mathrm{mM}$ sodium lactate as the electron donor. 

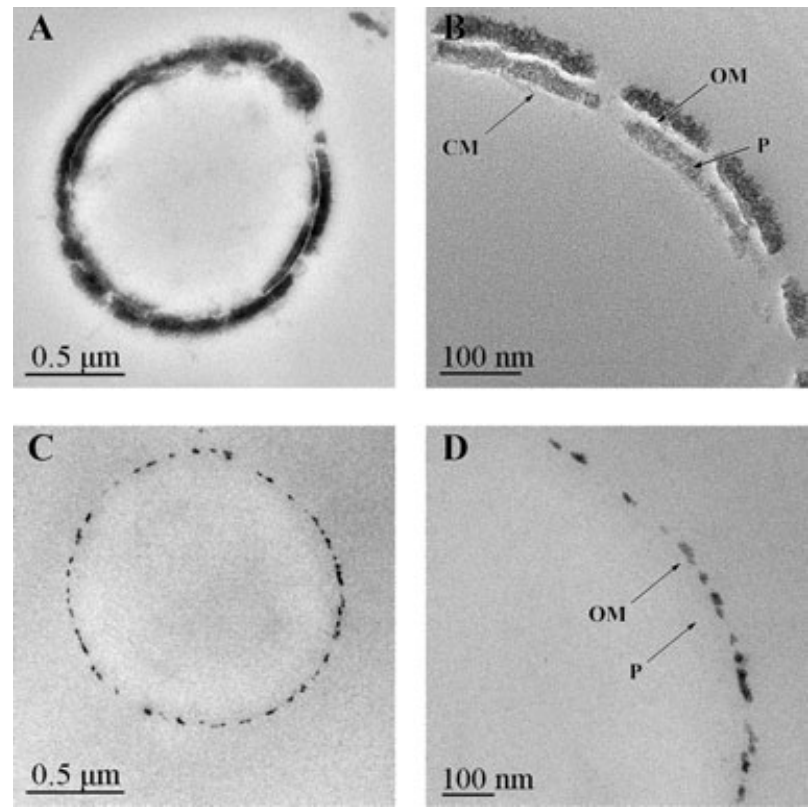

Fig. 3. $\mathrm{H}_{2}$-driven $\mathrm{TcO}_{2}$ localization in $\mathrm{S}$. oneidensis $\mathrm{MR}-1$ and the $\mathrm{NiFe}$ hydrogenase mutant cells. Transmission electron microscopy micrographs of thin sections prepared from cell suspensions incubated with $250 \mu \mathrm{M}$ ammonium pertechnetate and $10 \mathrm{ml}$ of $\mathrm{H}_{2}$. The localization of $\mathrm{TcO}_{2}$ in MR-1 at $24 \mathrm{~h}$ ( $\mathrm{A}$ and $\mathrm{B}$ ) was compared with NiFe hydrogenase mutant cells $\left(\mathrm{HyaB}^{-}\right)$at $48 \mathrm{~h}(\mathrm{C}$ and $\mathrm{D})$. Locations of the cell membrane $(\mathrm{CM})$, periplasm $(\mathrm{P})$ and outer membrane (OM) are shown.

using MR-1 and the above mutants (Table S1). In the presence of $\mathrm{H}_{2}, \mathrm{MR}-1$ and the Fe-only hydrogenase mutant $\left(\mathrm{HydA}^{-}\right)$were equally able to completely reduce $100 \mu \mathrm{M} \mathrm{Tc}(\mathrm{VII})$ within $24 \mathrm{~h}$. In contrast, both deletions of the NiFe hydrogenase $\left(\mathrm{HyaB}^{-}\right.$or $\left.\mathrm{HydA}^{-} / \mathrm{HyaB}^{-}\right)$reduced $13 \%$ of the $\mathrm{Tc}(\mathrm{VII})$ with $\mathrm{H}_{2}$ at $24 \mathrm{~h}$ and less than $40 \%$ at the assay conclusion (96 h). This limited reduction was comparable to the reduction observed by MR-1 cells not supplied an electron donor (Fig. S1). We attributed the partial reduction by both NiFe hydrogenase mutants to residual energy reserves in cells grown in rich medium and not another specific $\mathrm{H}_{2}$-driven $\mathrm{Tc}(\mathrm{VII})$ reduction mechanism. Compared with $\mathrm{H}_{2}$, lactate was a relatively poor electron donor for Tc(VII) reduction (Fig. 2). Wild-type MR-1 cells reduced only $23 \%$ and $56 \%$ of the initial $\mathrm{Tc}(\mathrm{VII})$ after 2 and 5 days respectively. Significantly, although the NiFe hydrogenase mutant was slower to reduce $\mathrm{Tc}(\mathrm{VII})$ using lactate as the electron donor, it still reduced $41 \%$ of the $\mathrm{Tc}(\mathrm{VII})$ during the 5-day assay.

The subcellular localization of $\mathrm{TcO}_{2}$ in wild-type MR-1 and the NiFe hydrogenase deletion mutant was determined by transmission electron microscopy (TEM) analysis of samples collected after the addition of $\mathrm{Tc}(\mathrm{VII})$ and $\mathrm{H}_{2}$ (Fig. 3). Thin sections of MR-1 revealed that electrondense $\mathrm{TcO}_{2}$ nanoparticles accumulated in the cell periplasm and on the outside face of the OM (Fig. 3 A and B).
Transmission electron microscopy analysis of the NiFe hydrogenase mutant revealed considerably lower relative abundance of $\mathrm{TcO}_{2}$ nanoparticles in association with cells than observed in the wild type (Fig. $3 \mathrm{C}$ and D). This was consistent with this mutant's impaired capacity to reduce $\mathrm{Tc}(\mathrm{VII})$. Similar to the wild type, the NiFe hydrogenase mutant localized $\mathrm{TcO}_{2}$ nanoparticles on the outside face of the OM. However, $\mathrm{TcO}_{2}$ nanoparticles were not observed within the periplasm of the NiFe hydrogenase mutant (Fig. 3D). In both mutant and wild-type cells, $\mathrm{TcO}_{2}$ nanoparticle localization was consistently cell-associated, consistent with enzymatic reduction. The electron-dense material observed in both samples, regardless of subcellular location, consisted of Tc nanoparticles with selected area diffraction (SAED) patterns consistent with those reported for synthetic and biogenic $\mathrm{Tc}(\mathrm{IV}) \mathrm{O}_{2}$ (data not shown).

Previous studies of global transcriptome patterns displayed by $S$. oneidensis MR-1 cells grown in the presence of different electron acceptors indicated that hydAB (the genes encoding the Fe-only hydrogenase) are upregulated four- to sixfold under thiosulfate-reducing conditions (Beliaev et al., 2005). Therefore, to ensure expression of the Fe-only hydrogenase, we induced cells deficient in functional NiFe hydrogenase $\left(\mathrm{HyaB}^{-}\right)$for $3 \mathrm{~h}$ with $1 \mathrm{mM}$ sodium thiosulfate prior to anoxic harvesting in preparation for resting-cell reduction assays. During the sample preparation, extreme caution was taken to minimize the cells exposure to $\mathrm{O}_{2}$ as it has been reported that the Fe-only hydrogenase in other organisms is $\mathrm{O}_{2}$-sensitive (Horner et al., 2000; Vignais and Colbeau, 2004; Ghirardi et al., 2005). NiFe hydrogenase mutant cells ( $\left.\mathrm{HyaB}^{-}\right)$ induced in this manner reduced $\sim 30 \%$ more $\mathrm{Tc}(\mathrm{VII})$ by $24 \mathrm{~h}$ than the non-induced NiFe hydrogenase mutant cells (Fig. 1) suggesting that the Fe-only hydrogenase can facilitate $\mathrm{Tc}(\mathrm{VII})$ reduction. The addition of heat-killed, thiosulfate-induced $\mathrm{NiFe}$ hydrogenase mutant cells did not reduce $\mathrm{Tc}(\mathrm{VII})$ in our assays (not shown).

\section{The $\mathrm{H}_{2}$-driven reduction of $\mathrm{Tc}(\mathrm{VII})$ by $\mathrm{S}$. oneidensis MR-1 does not have an absolute requirement for c-type cytochromes or menaquinone}

The importance of $c$-type cytochromes in Tc(VII) reduction was investigated using mutants with deletions of genes previously shown to be involved in electron transport coupled to metal and $\mathrm{U}(\mathrm{VI})$ reduction (Myers and Myers, 2000; Beliaev et al., 2001; Bencheikh-Latmani et al., 2005; Marshall et al., 2006) (Fig. 4 and Table S1). Resting-cell reduction assays with $\mathrm{Tc}(\mathrm{VII})$ and $\mathrm{H}_{2}$ demonstrated that in-frame deletion mutants lacking either the cell membrane (CM) tetrahaem cytochrome (cymA) or two decahaem OMCs ( $m$ trC and omcA) genes did not affect reduction compared with wild-type MR-1 cells (Fig. 4A). 
A

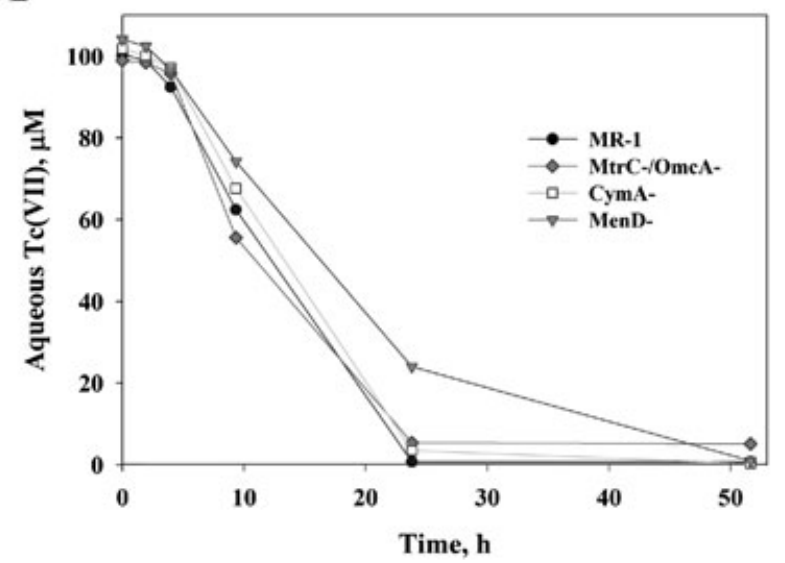

B

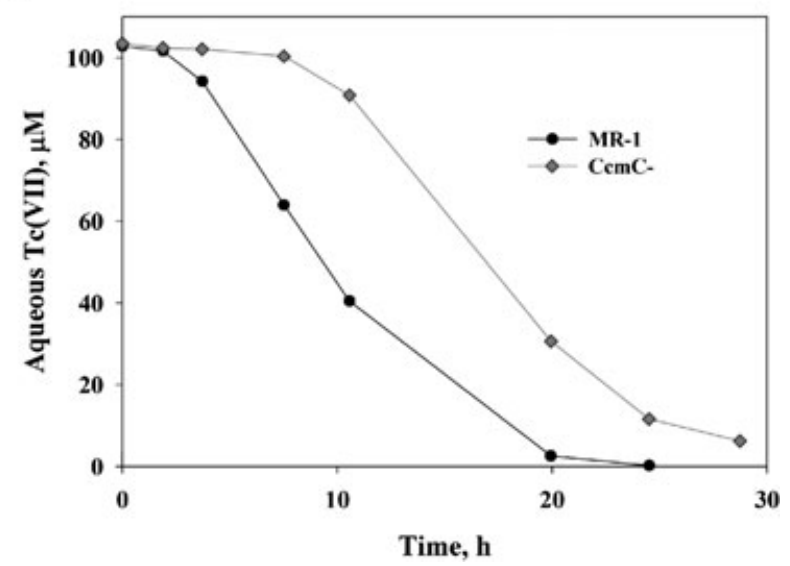

Fig. 4. $\mathrm{H}_{2}$-driven $\mathrm{Tc}(\mathrm{VII})$ reduction kinetics by $\mathrm{S}$. oneidensis $\mathrm{MR}-1$, cytochrome mutants and menaquinone deficient cells.

A. Tc(VII) reduction kinetics $(100 \mu \mathrm{M})$ was determined for MR-1, a single-cytochrome deletion mutant $\left(\mathrm{CymA}^{-}\right)$, a double-outer membrane cytochrome deletion mutant $\left(\mathrm{MtrC}^{-} / \mathrm{OmcA}^{-}\right)$and a mutant deficient in the production of menaquinone (MenD-). $B$. The reduction of $100 \mu \mathrm{M} \mathrm{Tc}(\mathrm{VII})$ was also determined for MR-1 and a mutant lacking all $c$-type cytochromes $\left(\mathrm{CcmC}^{-}\right)$.

Ten $\mathrm{ml}$ of $\mathrm{H}_{2}$ was used as the as the electron donor for all experiments.

To further investigate the involvement of $c$-type cytochromes in $\mathrm{Tc}(\mathrm{VII})$ reduction, a previously described S. oneidensis MR-1 mutant lacking the ability to covalently incorporate haem into nascent apocytochromes $\left(\mathrm{CcmC}^{-}\right)$(Bouhenni et al., 2005) was tested. The $\mathrm{CcmC}^{-}$mutant was previously shown to be unable to reduce uranyl(VI) carbonate complexes to uraninite (Marshall et al., 2006). The $\mathrm{CcmC}^{-}$mutant was significantly slower than MR-1 at transferring electrons to $\mathrm{Tc}(\mathrm{VII})$ $(P<0.001)$, but did not abolish the ability of cells to quantitatively reduce $100 \mu \mathrm{M} \mathrm{Tc}(\mathrm{VII})$ to $\mathrm{Tc}(\mathrm{IV})$ (Fig. 4B). This indicated that functional $c$-type cytochromes were not an absolute requirement for electron transfer to $\mathrm{Tc}(\mathrm{VII})$.

We also investigated the role of intermediary electron shuttling components in Tc(VII) reduction. Menaquinone is a lipid-soluble component of electron transport chains involved in anaerobic respiration and is an intermediate carrier of electrons to terminal reductase complexes (Saffarini et al., 2002). An interruption of the menDHCE operon $\left(\mathrm{MenD}^{-}\right)$was used to determine the role of menaquinone in $\mathrm{H}_{2}$-driven resting-cell $\mathrm{Tc}(\mathrm{VII})$ reduction assays. At $24 \mathrm{~h}$, the MenD- mutant cells reduced only $75.4 \%$ of the $\mathrm{Tc}(\mathrm{VII})$ compared with wild-type cells (Fig. 4A), but by the assay conclusion completely reduced $100 \mu \mathrm{M} \mathrm{Tc}(\mathrm{VII})$.

\section{OMCs can reduce $T c$ (VII)}

As the NiFe hydrogenase mutant reduced only $15 \%$ less $\mathrm{Tc}(\mathrm{VII})$ than wild-type MR-1 using lactate as the electron donor, we investigated the lactate-driven $\mathrm{Tc}(\mathrm{VII})$ reduction capability of the $c$-type cytochrome mutants, $\mathrm{CcmC}^{-}$and $\mathrm{MtrC}^{-} / \mathrm{OmcA}^{-}$(Fig. 2 and Table S1). We found that these mutants were deficient, relative to the wild type, in the ability to reduce $\mathrm{Tc}(\mathrm{VII})$. In a 5-day resting-cell assay, these mutants reduced only $12 \%$ of the available $\mathrm{Tc}(\mathrm{VII})$. Under the same conditions, wild-type MR-1 reduced more than fourfold the amount of $\mathrm{Tc}(\mathrm{VII})$.

To evaluate whether reduced OMCs can directly transfer electrons to pertechnetate we evaluated whether purified, reduced MtrC or OmcA was oxidized upon exposure to $\mathrm{Tc}(\mathrm{VII}) \mathrm{O}_{4}{ }^{-}$in vitro. Reactivity did occur and the specific activities of MtrC and OmcA towards Tc were $56.9 \pm 9.4$ and $4.2 \pm 0.6$ nmole $\mathrm{mg}^{-1} \mathrm{~min}^{-1}$ respectively. In contrast, no detectable oxidation of either OMC was observed when mixed with the anoxic water alone.

The role of hydrogenase in the reduction of other metals

To determine the role of the $S$. oneidensis MR-1 hydrogenases in the reduction of $\mathrm{U}(\mathrm{VI}), \mathrm{Fe}(\mathrm{III}), \mathrm{Mn}(\mathrm{IV}), \mathrm{Co}(\mathrm{III})$ and $\mathrm{V}(\mathrm{V})$, we tested wild-type MR-1 and the hydrogenase mutants in resting-cell reduction assays using either $\mathrm{H}_{2}$ or lactate as the sole electron donor (Fig. S2). When lactate was used as the electron donor, neither the Fe-only nor the NiFe hydrogenase was required for electron transfer. Additionally, a deletion of the Fe-only hydrogenase did not inhibit the cells ability to reduce these metals with $\mathrm{H}_{2}$. In contrast, when $\mathrm{H}_{2}$ was used as the sole electron donor, deletions of the NiFe hydrogenase (either $\mathrm{HyaB}^{-}$or $\mathrm{HydA}^{-} / \mathrm{HyaB}^{-}$) lacked the ability to transfer electrons to these metals. The induction of the Fe-only hydrogenase restored the $\mathrm{H}_{2}$-driven ability of NiFe hydrogenase mutant cells to reduce metals (Fig. S2B, F and $\mathrm{H}$ ), while the complementation of the hyaB gene deletion $\left[\mathrm{HyaB}^{-}\right.$ (+pCR4-hyaB)] restored the ability of the NiFe hydrogenase mutant to reduce both $\mathrm{U}(\mathrm{VI})$ and hydrous ferric oxide (HFO) (Fig. S3). 


\section{Discussion}

This is the first report of a $\mathrm{Tc}(\mathrm{VII})$ reductase activity attributable to the $c$-type cytochromes, specifically the OMCs, MtrC and OmcA. While there has not been direct evidence of the $c$-type cytochrome facilitated $\mathrm{Tc}(\mathrm{VII})$ reduction in any DMRB, Wildung and colleagues (2000) first speculated that the OMCs of Shewanella would be theoretically capable of reducing $\mathrm{TcO}_{4}^{-}$. The slower $\mathrm{TcO}_{4}^{-}$ reduction kinetics of MR-1 cells lacking all functional c-type cytochromes $\left(\mathrm{CcmC}^{-}\right)$suggested that these proteins play a role in $\mathrm{H}_{2}$-driven $\mathrm{Tc}(\mathrm{VII})$ reduction. We also demonstrated that MR-1 c-type cytochromes (MtrC and OmcA) functioned as reductases of Tc(VII) when coupled to the oxidation of lactate. This also validated our prediction that the bidirectional hydrogenase was not the exclusive $\mathrm{Tc}(\mathrm{VII})$ reductase and that an alternative mechanism for electron transfer to $\mathrm{Tc}(\mathrm{VII})$ existed in $\mathrm{S}$. oneidensis MR-1.

Results from the whole-cell assays were consistent with the finding that purified, reduced OMCs were oxidized by $\mathrm{Tc}(\mathrm{VII}) \mathrm{O}_{4}^{-}$in a defined in vitro system. It was not surprising that purified MtrC was at least an order of magnitude faster to transfer electrons to $\mathrm{Tc}(\mathrm{VII})$ than that of OmcA. We recently demonstrated that MtrC efficiently transferred electrons to uranyl citrate, while reduced OmcA was not oxidized by $\mathrm{U}(\mathrm{VI})$ within the same time frame (Marshall et al., 2006). The electron transfer rates to $\mathrm{Tc}(\mathrm{VII}) \mathrm{O}_{4}{ }^{-}$were at least an order of magnitude slower than the reported electron transfer rates to soluble Fe(III)-NTA (Shi et al., 2006) for either $\operatorname{MtrC}\left(\mathrm{Tc}=0.069 \pm 0.011 \mathrm{~S}^{-1}\right.$ compared with $\left.\mathrm{Fe}=2.0 \pm 0.2 \mathrm{~S}^{-1}\right)$ or $\mathrm{OmcA}(\mathrm{Tc}=0.0056 \pm$ $0.0008 \mathrm{~S}^{-1}$ compared with $\mathrm{Fe}=1.5 \pm 0.2 \mathrm{~S}^{-1}$ ), in spite of the fact that the initial concentration of Tc provided was greater than the concentration of $\mathrm{Fe}(\mathrm{III})$ in the respective assays. The electrode potential $\left(\mathrm{E}^{\circ}\right)$ of the $\mathrm{Tc}(\mathrm{VII}) \mathrm{O}_{4}{ }^{-}-$ $\mathrm{Tc}(\mathrm{IV}) \mathrm{O}_{2} \cdot \mathrm{nH}_{2} \mathrm{O}$ couple is $746 \mathrm{mV}$ at the standard state (Rard et al., 1999) and $154 \mathrm{mV}$ at $\mathrm{pH} 7.5$ after correction for $\mathrm{pH}$ effects based on the redox reaction: $\mathrm{Tc}(\mathrm{VII}) \mathrm{O}_{4}{ }^{-}$ $+4 \mathrm{H}^{+}+3 e^{-}=\mathrm{TcO}_{2}-\mathrm{nH}_{2} \mathrm{O}+2-\mathrm{nH}_{2} \mathrm{O}$. As a comparison, at circumneutral $\mathrm{pH}$ the haems titrate over a range from -35 to $-220 \mathrm{mV}$ for OmcA and from -80 to $-160 \mathrm{mV}$ for MtrC (D. Richardson, pers. comm.), indicating that it is thermodynamically feasible for either of these two OMCs to reduce $\mathrm{Tc}(\mathrm{VII})$ to $\mathrm{Tc}(\mathrm{IV})$ over the concentration range used in this study.

Studies of $\mathrm{Tc}(\mathrm{VII})$ reduction in other organisms suggested that hydrogenase was involved in anaerobic electron transport to $\mathrm{TcO}_{4}{ }^{-}$(Lloyd et al., 1999b; 2000; De Luca et al., 2001). The involvement of Shewanella hydrogenases in the reduction of $\mathrm{Tc}(\mathrm{VII})$ was first proposed by Wildung and colleagues (2000) because of their significant homology to periplasmic hydrogenases produced by Desulfovibrio. To date, the precise biomolecular mecha- nisms of $\mathrm{Tc}(\mathrm{VII})$ reduction by $\mathrm{S}$. oneidensis MR-1 have not been identified. In this study, we established that the NiFe hydrogenase of MR-1 was essential for the rapid and complete reduction of $\mathrm{Tc}(\mathrm{VII})$ using $\mathrm{H}_{2}$ as the electron donor. NiFe hydrogenase-deficient cells grown under conditions where the Fe-only hydrogenase was expressed reduced Tc(VII) at near wild-type MR-1 rates. Presumably, these reductions were attributable to the ability of hydrogenases to directly couple $\mathrm{H}_{2}$ oxidation with $\mathrm{Tc}(\mathrm{VII})$ reduction as observed in Desulfovibrio fructosovorans (De Luca et al., 2001). Although the electrochemical properties of the MR-1 hydrogenases have not been determined, the [4Fe-4S] clusters of the Desulfovibrio gigas NiFe hydrogenase have mid-point potentials of -290 and $-340 \mathrm{mV}$ (Teixeira et al., 1989). If the mid-point potentials of the MR-1 and $D$. gigas NiFe hydrogenase were similar, then it would also be thermodynamically plausible for MR-1 hydrogenase to reduce $\mathrm{Tc}(\mathrm{VII})$ to $\mathrm{Tc}(\mathrm{IV})$. Additional studies to characterize these biochemical properties of the MR-1 hydrogenases are currently in progress.

Our findings suggested that the NiFe hydrogenase was the dominant uptake hydrogenase associated with the $\mathrm{H}_{2}$-driven reduction of $\mathrm{Tc}(\mathrm{VII})$ or other metals by MR-1 under the specific assay conditions examined herein. This finding was in agreement with another recent report on the functions of the MR-1 hydrogenases (MeshulamSimon et al., 2007). Hydrogenase, however, was not an absolute requirement for reduction by MR-1 as deletion of hydrogenases did not completely abolish the ability of cells to transfer electrons to $\mathrm{Tc}(\mathrm{VII})$ either with $\mathrm{H}_{2}$ (Fig. 1) or with lactate (Fig. 2). This suggested that MR-1 has another mechanism of electron transfer to $\mathrm{Tc}(\mathrm{VII})$ in addition to hydrogenase, but that the kinetics of this alternative mechanism are significantly slower. Experiments investigating the NiFe hydrogenase mutants ability to reduce $\mathrm{Tc}(\mathrm{VII})$ coupled to lactate oxidation revealed that this mutant reduced $\mathrm{Tc}(\mathrm{VII})$ at a rate nearly equal to the wildtype MR-1. While this result was consistent with the previous finding that electron donor-specific $\mathrm{Tc}(\mathrm{VII})$ reduction-deficient mutants of Shewanella could be isolated (Payne and DiChristina, 2006), it contrasted with reports that other organisms such as $G$. sulfurreducens and $D$. fructosovorans can only couple $\mathrm{Tc}(\mathrm{VII})$ reduction with $\mathrm{H}_{2}$ oxidation (Lloyd et al., 2000; De Luca et al., 2001).

Studies on the role(s) of $c$-type cytochromes in the reduction of $\mathrm{U}(\mathrm{VI})$ have been focused on determining the terminal reductase(s) of $\mathrm{U}(\mathrm{VI})$ and hence the role of electron donor type was not considered (Bencheikh-Latmani et al., 2005; Marshall et al., 2006). While lactate oxidation was coupled to $c$-type cytochrome-dependent reduction of $\mathrm{U}(\mathrm{VI})$ (Marshall et al., 2006), the reduction of $\mathrm{U}(\mathrm{VI})$ by $c$-type cytochromes is not linked to the specific type of electron donor supplied as the addition of $\mathrm{H}_{2}$ results in a similar c-type cytochrome-dependent reduction of 
$\mathrm{U}(\mathrm{VI})$ (Fig. S4A). Therefore, we conclude that c-type cytochrome-facilitated $\mathrm{U}(\mathrm{VI})$ reduction is independent of electron donor type even though some differences in electron donor specific-kinetic rates among different dissimilatory metal-reducing Shewanella have been reported (Liu et al., 2002). In contrast, the specific rate of $\mathrm{H}_{2}$-driven $\mathrm{Tc}(\mathrm{VII})$ reduction for wild-type MR-1 was approximately tenfold higher than when lactate was provided as an electron donor (Table S1). Similarly, the $\mathrm{H}_{2}$-driven specific rate of $\mathrm{Tc}(\mathrm{VII})$ reduction has been reported to be significantly faster than the formate-driven reduction in Desulfovibrio desulfuricans (Lloyd et al., 1999b). These donor-specific rate differences for $\mathrm{Tc}(\mathrm{VII})$ reduction may be related to the low potentials of the intermediate Tc valence states $[\mathrm{Tc}(\mathrm{VI})=-640 \mathrm{mV}$, and $\mathrm{Tc}(\mathrm{V})=-600 \mathrm{mV}]$ (Rard et al., 1999) that, once formed, rapidly disproportionate to yield $\mathrm{Tc}(\mathrm{IV})$ as a stable product. The low potential, intermediate valence states act as a thermodynamic barrier in the $\mathrm{Tc}(\mathrm{VII})$ to $\mathrm{Tc}(\mathrm{IV})$ redox reaction. The lower mid-point potential of $D$. gigas NiFe hydrogenases $(-290$ to $-340 \mathrm{mV}$ ) as compared with those of either MtrC or OmcA $(-35$ to $-220 \mathrm{mV})$ indicates that the former proteins should be more able to drive the reduction reaction through the problematic intermediate states. If the MR-1 NiFe hydrogenase possesses a mid-point potential similar to $D$. gigas, then it would also be thermodynamically plausible for MR-1 hydrogenase to drive the reduction reaction in a similar fashion. These differences may explain the relative rates of $\mathrm{Tc}(\mathrm{VII})$ reduction via the $\mathrm{H}_{2}$-hydrogenase and lactate-OMC pathways. In contrast, the electrode potentials for the reaction of $\mathrm{U}(\mathrm{VI})$ to $\mathrm{U}(\mathrm{V})(90 \mathrm{mV})$ or $\mathrm{U}(\mathrm{VI})$ to $\mathrm{U}(\mathrm{IV})(1870 \mathrm{mV}$ ) (Guillaumont et al., 2003) are considerably more thermodynamically favourable for efficient electron transfer by the OMCs.

Under conditions where $\mathrm{H}_{2}$ and organic compounds are available electron donors, it is likely that both the hydrogenase- and cytochrome-mediated Tc(VII) reduction processes are functioning concurrently. Other researchers have reported the close physical association of hydrogenase and c-type cytochrome (Peck, 1993; De Luca et al., 2001). The formate hydrogenlyase complex in Desulfovibrio consists of a formate dehydrogenase, linked to a hydrogenase via a cytochrome (Peck, 1993). A small periplasmic $c$-type cytochrome was also associated with the $D$. fructosovorans NiFe hydrogenase in vitro $\mathrm{Tc}(\mathrm{VII})$ reductase activity (De Luca et al., 2001). They reported that purified hydrogenase reduced $\mathrm{Tc}(\mathrm{VII})$ in assays amended with $\mathrm{H}_{2}$.

Previously, we determined that biogenic $\mathrm{UO}_{2}$ nanoparticles localized not only within the cell periplasm and at the surface of OM (as seen in Fig. 3), but also with a complex exopolymeric substance (EPS) (Marshall et al., 2006). In the current study, we did not observe the formation of a similar $\mathrm{TcO}_{2}$-EPS matrix with either the wild-type MR-1 or
$\mathrm{NiFe}$ hydrogenase mutant cells. Instead, $\mathrm{TcO}_{2}$ nanoparticles were localized only to the cell surface, in agreement with previous observations (Lloyd et al., 2000; Wildung et al., 2000). The absence of a $\mathrm{TcO}_{2}$-EPS matrix could not be attributable to electron donor supplied in our assays as $\mathrm{UO}_{2}$ nanoparticles were also localized with EPS when $\mathrm{H}_{2}$ was supplied as the sole electron donor (Fig. S4B). The difference between $U$ and Tc nanoparticle localization may be explained by the periplasmic localization of the NiFe hydrogenase and its role of $\mathrm{H}^{+}$production and $\mathrm{Tc}(\mathrm{VII})$ reduction during $\mathrm{H}_{2}$-driven electron transfer to $\mathrm{Tc}(\mathrm{VII})$. In contrast, the redundant network of $c$-type cytochromes involved in reduction of $\mathrm{U}(\mathrm{VI})$ are localized not only within the periplasm, but also are found outside of the OM, either attached to the outside face or associated with EPS (Myers and Myers, 2003a; Marshall et al., 2006). Consequently, wild-type MR-1 cells accumulated a large portion of $\mathrm{TcO}_{2}$ nanoparticles in their periplasmic space whereas $\mathrm{UO}_{2}$ nanoparticles were more evenly distributed between the periplasm and exterior of the cell. Cells lacking functional NiFe hydrogenase accumulate $\mathrm{TcO}_{2}$ nanoparticles only at the OM surface, presumably due to the localization of OMCs; however, these cells are slow to reduce Tc(VII) relative to wild-type MR-1. The relatively slow electron transfer rates to $\mathrm{Tc}(\mathrm{VII})$ from both $\mathrm{MtrC}$ and OmcA (independent of electron donor source) would explain why the NiFe hydrogenase mutant does not accumulate large quantities of $\mathrm{TcO}_{2}$ at the $\mathrm{OM}$ surface during assay conditions where $\mathrm{Tc}(\mathrm{VII})$ reduction by OMCs would be the sole reduction pathway. The localization of $\mathrm{TcO}_{2}$ at the $\mathrm{OM}$ surface of the NiFe hydrogenase mutant, in conjunction with the lactate-driven $\mathrm{Tc}(\mathrm{VII})$ reduction kinetics for both the $\mathrm{CcmC}^{-}$and $\mathrm{MtrC}^{-} / \mathrm{OmcA}^{-}$mutants, suggested that $\mathrm{MtrC}$ and OmcA are the principal reductases in the $c$-type cytochrome-mediated Tc(VII) reduction pathway. Understanding the relationship between the electron donor and subcellular fate of $\mathrm{TcO}_{2}$ nanoparticles could potentially be important in the environment where oxidants such as $\mathrm{O}_{2}$ or $\mathrm{MnO}_{2}$ may also be present or where colloidal transport could be facilitated.

This report is the first to systematically investigate the role of hydrogenases and the electron transfer system of S. oneidensis MR-1 in the reduction of highly mobile pertechnetate anions. We present a $\mathrm{Tc}(\mathrm{VII})$ reductase activity by at least two $c$-type cytochromes. We also conclusively show that the NiFe hydrogenase and, to a lesser degree, the Fe-only hydrogenase play a more direct role in the reduction of $\mathrm{Tc}(\mathrm{VII})$ than just the production of $\mathrm{H}^{+}$for subsequent electron transfer reactions. Furthermore, we demonstrate that the source of electron donor may be advantageous for the selection of either the hydrogenase or the c-type cytochrome mediated Tc(VII) reduction pathway in vivo. Although the kinetics of lactate-driven $\mathrm{Tc}(\mathrm{VII})$ reduction may be slower than $\mathrm{H}_{2}$-driven reduction 
Table 2. Primers used in this study.

\begin{tabular}{|c|c|}
\hline Primer name & Nucleotide sequence ${ }^{a}$ \\
\hline \multicolumn{2}{|c|}{$\Delta \mathrm{SO} 3920\left(\right.$ hydA $\left.A^{-}\right)$} \\
\hline 3920_F-O & 5'-CCCATTAGCCTTTCGTGATG-3' \\
\hline 3920_5-0 & 5'-ACCGTTCAAGAAATATTCC-3' \\
\hline 3920_5-I & 5'-CCСATCCACTAAACTTAAACACGATAGAGTGTACTGCACCC-3' \\
\hline 3920_3-I & 5'-TGTTTAAGTTTAGTGGATGGGGAGGTGATGAACTGCGCTGG-3' \\
\hline 3920_3-0 & 5'-CCCCCCGGGAGCGGTTTAAAAAACAATAG-3' \\
\hline 3920_R-O & 5'-GGGCGATGAACAGTACCACT-3' \\
\hline \multicolumn{2}{|c|}{$\Delta \mathrm{SO} 2098($ hyaB-) } \\
\hline 2098_F-O & 5'-CAATAACGGCAGTTTCTTAAC-3' \\
\hline $2098+5-0$ & 5'-AGGATAGAGCTCTGCACGAAGTGGTCAGCAAA-3' \\
\hline 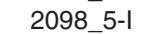 & 5'-CCСATCCACTAAACTTAAACACGTAGAGGATGACCATGCTT-3' \\
\hline 2098_3-I & 5'-TGTTTAAGTTTAGTGGATGGGCCTTGCATGGCGTGTTCAGT-3' \\
\hline $2098+3-0$ & 5'-AGGATAAAGCTTCCGTGATCCAAGCTGCACTG-3' \\
\hline 2098_R-O & 5'-ATGCCCAAGTGAGGTAGTGG-3' \\
\hline \multicolumn{2}{|c|}{$\Delta \mathrm{SO} 4591\left(\right.$ cymA $\left.^{-}\right)$} \\
\hline 4591_F-O & 5'-GCATGACTCATTAATACCA-3' \\
\hline 4591_5-O & 5'-GTCTTGGCAATGAATCATGCA-3' \\
\hline 4591_5-I & 5'-GTGTAGCGTTGTGTCTGCCCACCAGTTCATTACTCTATCTCCA-3' \\
\hline $45913-1$ & 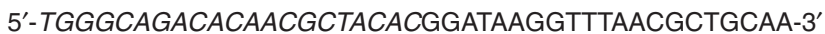 \\
\hline 4591_3-0 & 5'-TGACGACTCACAATCACATGA-3' \\
\hline 4591_R-O & 5'-GCGCAAACTGCTCTCACTA-3' \\
\hline \multicolumn{2}{|c|}{ pCR4-hyaB complementation } \\
\hline HyaB_F & 5'-CACCTAACCAAGCCGCTGGAGGAATAAC-3' \\
\hline HyaB_R & 5'-TTATTGACCATTGGGGCTGAC-3' \\
\hline
\end{tabular}

a. Sequences in italics are added to facilitate fusion of first-round PCR amplicons as described by Link and colleagues (1997).

in the laboratory, the implications of understanding both $\mathrm{Tc}(\mathrm{VII})$ reduction mechanisms could potentially be important in the environment where organic electron donor concentrations may be high relative to $\mathrm{H}_{2}$. Alternatively, the relatively slow lactate-driven $\mathrm{Tc}(\mathrm{VII})$ reduction rates may suggest that the $c$-type cytochrome-mediated pathway will not be an important route in environments where $\mathrm{H}_{2}$ or $\mathrm{Fe}(\mathrm{II})$ is high as hydrogenase-mediated or abiotic reduction rates (Fredrickson et al., 2004) may likely be much faster. Together, these findings could significantly influence the future design of in situ biostimulation/bioremediation strategies designed to exploit the biogenic $\mathrm{Tc}(\mathrm{VII})$ reduction and the subsequent formation of $\mathrm{Tc}(\mathrm{IV}) \mathrm{O}_{2}$ nanoparticles which would reduce Tc solubility, and hence mobility in the subsurface.

\section{Experimental procedures}

\section{Chemicals and media}

All chemicals used in this study were purchased from Sigma Chemical (St. Louis, MO) unless otherwise noted. Growth media were purchased from BD Diagnostics (Sparks, MD).

\section{Generation of in-frame deletion mutants and complementation vector}

Shewanella oneidensis MR-1 mutants lacking selected hydrogenase or $c$-type cytochrome genes were constructed using two-step homologous recombination with a suicide plasmid encoding flanking DNA sequence using a modifica- tion of previously described methods (Link et al., 1997; Wan et al., 2004). Primer sequences, plasmids and strains used in this study are described in detail in Tables 1 and 2. Shewanella oneidensis MR-1 and Escherichia coli strains used for mutagenesis were grown using Luria-Bertani (LB) medium at $30^{\circ} \mathrm{C}$ and $37^{\circ} \mathrm{C}$ respectively. The plasmid pDS3.1 was purified from E. coli using the Qiagen QIAprep Spin Miniprep Kit (Qiagen, Valencia, CA) and digested with Xcml [New England Biolabs (NEB), Beverly, MA]. Shewanella oneidensis chromosomal DNA was isolated using DNAzol (Invitrogen, Carlsbad, CA) and used as the template for polymerase chain reaction (PCR) amplification using Vent DNA polymerase (NEB). Sequences that flank the respective genes targeted for deletion were joined by amplifying each locus with 5-O/5-I and 3-O/3-I primer pairs, annealing them via complementary sequences present in the 5-I and 3-I primers, and then subjected to a second round of PCR using the 5-O and 3-O primers as described (Link et al., 1997). The fusion PCR amplicon was purified using $1 \%$ agarose electrophoresis (Sambrook et al., 1989) and ligated into the pDS3.1 plasmid using the FastLink Ligation kit (Epicentre, Madison, WI) prior to transformation into E. coil EC100D pir-116 (Epicentre) (Hanahan, 1983) and plating on LB with gentamicin selection $\left(15 \mu \mathrm{g} \mathrm{ml}^{-1}\right)$. Correct transformants were verified by PCR using the $5-\mathrm{O}$ and $3-\mathrm{O}$ primers and the plasmids were purified and transformed into the E. coli $\beta-2155$ mating strain by plating on gentamicin $\left(15 \mu \mathrm{g} \mathrm{ml}^{-1}\right)$ and diaminopimelic acid $\left(100 \mu \mathrm{g} \mathrm{ml}^{-1}\right)$ selection. Conjugal transfer of plasmid and homologous recombination from E. coli mating strain to $S$. oneidensis was performed (de Lorenzo et al., 1990) and primary integrants were selected with gentamicin $\left(7.5 \mu \mathrm{g} \mathrm{ml}^{-1}\right)$. Polymerase chain reaction screening for homologous recombination of the plasmid and the insertion site of amplicon recombination within the genome were 
accomplished using the $\mathrm{F}-\mathrm{O} / 3-\mathrm{O}$ or $5-\mathrm{O} / \mathrm{R}-\mathrm{O}$ primer pairs. Sucrose sensitivity of the primary integrants was verified by plating on LB- $\mathrm{NaCl}+10 \%$ sucrose (Blomfield et al., 1991). The second homologous recombination was selected for by growing the primary integrant for $16-18 \mathrm{~h}$ in $\mathrm{LB}-\mathrm{NaCl}$ broth cultures followed by plating on $\mathrm{LB}-\mathrm{NaCl}+10 \%$ sucrose. Colonies sensitive to gentamicin $\left(7.5 \mu \mathrm{g} \mathrm{ml}^{-1}\right)$ were screened for deletion of the gene of interest by PCR using the F-O/R-O primer set and compared with the same fragment amplified from wild-type MR-1. The PCR amplicon generated from the mutants with the F-O/R-O primer set was used as the template for DNA sequencing of the deleted gene(s) and recombination regions (ACGT, Wheeling, IL).

The complementation of the hyaB deletion was accomplished by PCR amplification of the hyaB coding sequence from S. oneidensis chromosomal DNA with the HyaB_F and HyaB_R primer set and cloning into the $\mathrm{PCR}^{\circledR} 4-\mathrm{TOPO}^{\circledR}$ vector (Invitrogen) prior to transformation into E. coli Top10 (Invitrogen) and plating on LB with kanamycin selection (50 $\left.\mathrm{g} \mathrm{ml}^{-1}\right)$ (Table 1). Correct transformants were verified by PCR amplification. The pCR4-hyaB plasmid was purified and transferred into NiFe hydrogenase mutant cells [HyaB- (+pCR4-hyaB)] by electroporation using previously described protocols (Hanahan, 1983; 1985). Antibiotic selection [kanamycin $\left.\left(50 \mu \mathrm{g} \mathrm{ml}^{-1}\right)\right]$ was maintained to ensure stability of the pCR4hyaB plasmid in all cultures except for the resting-cell reduction assay tubes. The PCR amplicon generated using the HyaB_F and HyaB_R primer set was used as the template for DNA sequencing of the hyaB complementation plasmid.

\section{Tc(VII) reduction assay conditions}

The kinetics of aqueous $\mathrm{Tc}(\mathrm{VII})$ reduction and localization in wild-type MR-1 and mutant cells were determined in a standard resting-cell assay. Tryptic soy broth without dextrose (TSB-dex) cultures $(100 \mathrm{ml})$ was grown for $16 \mathrm{~h}\left(30^{\circ} \mathrm{C}\right)$ at 100 r.p.m. and harvested by centrifugation (5000 $\mathrm{g}, 5 \mathrm{~min}$ ). Cells were washed once in equal volume of $30 \mathrm{mM}$ piperazine- $N, N^{\prime}$-bis(ethanesulfonic acid) (PIPES) buffer $\left(\mathrm{pH} 7.0,4^{\circ} \mathrm{C}\right)$, pelleted, re-suspended in the fresh buffer at a concentration of $2 \times 10^{9}$ cells $\mathrm{ml}^{-1}$ and purged for $\sim 10 \mathrm{~min}$ with $\mathrm{N}_{2}$ gas. $\mathrm{Tc}(\mathrm{VII})$ reduction assays contained a final concentration of $100 \mu \mathrm{M}$ ammonium pertechnetate $\left[\mathrm{NH}_{4}{ }^{99} \mathrm{Tc}(\mathrm{VII}) \mathrm{O}_{4}\right.$ ] (Perkin-Elmer, Boston, MA) in $30 \mathrm{mM}$ PIPES purged with $\mathrm{O}_{2}$-free $\mathrm{N}_{2}$ and sealed with thick butyl rubber stoppers. The electron donors used in all studies were either $10 \mathrm{ml}$ of $\mathrm{H}_{2}$ or $5 \mathrm{mM}$ sodium lactate. Kinetic studies were initiated by the addition of $1 \mathrm{ml}$ of standardized cells, resulting in a final assay density of $2 \times 10^{8}$ cells $\mathrm{ml}^{-1}$, to the assay tubes followed by horizontal (lactate) or inverted $\left(\mathrm{H}_{2}\right)$ incubation at $30^{\circ} \mathrm{C}$ with slow gyratory shaking (75 r.p.m.). The amount of soluble $\mathrm{Tc}(\mathrm{VII})$ remaining in all samples was analysed at multiple time points by liquid scintillation counting of ${ }^{99} \mathrm{Tc}(0.292 \mathrm{MeV}$ beta) as previously described (Fredrickson et al., 2000; Wildung et al., 2000). Samples using $\mathrm{H}_{2}$ as the electron donor could be directly counted, whereas samples using lactate as the electron donor required complexation with tetraphenyl arsonium chloride (TPAC) at a 40:1 molar ration and extracting the $\mathrm{TPAC}-\mathrm{TCO}_{4}{ }^{-}$complex from the soluble phase with chloroform prior to liquid scintillation counting (Tribalat and Beydon, 1953; Wildung et al., 2000).
Expression of the Fe-only hydrogenase (HydAB) was accomplished by induction with thiosulfate. At 13 hours post inoculation at $30^{\circ} \mathrm{C}$ (100 r.p.m.), a TSB-dex culture (100 ml) of the $\mathrm{NiFe}$ hydrogenase mutant $\left(\mathrm{HyaB}^{-}\right)$was harvested by centrifugation $(5000 \mathrm{~g}, 5 \mathrm{~min})$ at room temperature and re-suspended in an equal volume of anaerobic minimal media (Beliaev et al., 2005) containing $1 \mathrm{mM}$ sodium thiosulfate and $20 \mathrm{mM}$ sodium lactate. The medium was purged for $10 \mathrm{~min}$ with $\mathrm{N}_{2}$ and sealed. Cells were grown for an additional $3 \mathrm{~h}$ $\left(30^{\circ} \mathrm{C}\right)$ at 100 r.p.m. and harvested as described above except that an additional wash step was included to ensure complete removal of thiosulfate prior to the addition of pertechnetate (or other electron acceptor). During harvest and preparation for kinetic assays, cells were kept under $\mathrm{N}_{2}$ and all solutions used were anoxic $\left(4^{\circ} \mathrm{C}\right)$. For all experiments, $\mathrm{H}_{2}(10 \mathrm{ml})$ was used as the electron donor. To ensure that the thiosulfate in the defined media was completely removed from reduction assays, an aliquot of washed $\mathrm{NiFe}$ hydrogenase mutant $\left(\mathrm{HyaB}^{-}\right)$cells was heat-killed and added to an identical set of assay tubes.

\section{Uranium and metal reduction coupled to lactate or $\mathrm{H}_{2}$ oxidation}

For additional phenotype characterizations, $16 \mathrm{~h}$ TSB-dex cultures were grown and washed as described above except that a $30 \mathrm{mM}$ sodium bicarbonate buffer $\left(\mathrm{pH} 7.0,4^{\circ} \mathrm{C}\right)$ was substituted for the $30 \mathrm{mM}$ PIPES buffer. Standardized cell suspensions $\left(2 \times 10^{9}\right.$ cells ml$\left.{ }^{-1}\right)$ were purged for $\sim 10 \mathrm{~min}$ with $\mathrm{O}_{2}$-free mixed gas $\left[\mathrm{N}_{2}: \mathrm{CO}_{2}(80: 20)\right]$. Reduction assays were conducted in $30 \mathrm{mM}$ sodium bicarbonate buffer $(\mathrm{pH} 7.0)$ and contained a final concentration of either $250 \mu \mathrm{M} \mathrm{U}(\mathrm{VI})$, as uranyl acetate, $1.0 \mathrm{mM}$ ferric(III)-nitrilotriacetic acid (NTA), $10 \mathrm{mM}$ silica-ferrihydrite (Si-HFO) (Kukkadapu et al., 2004), $1.0 \mathrm{mM}$ cobalt(III)-ethylenediaminetetraacetic acid (EDTA), $10 \mathrm{mM}$ sodium vanadate $(\mathrm{V})$ or $1.0 \mathrm{mM}$ manganese as vernadite $\left[\mathrm{Mn}(\mathrm{IV}) \mathrm{O}_{2}\right]$. In all assays, either $\mathrm{H}_{2}(10 \mathrm{ml})$ or sodium lactate (20 mM for tubes containing Si-HFO and $10 \mathrm{mM}$ for all other electron donors) was added the sole electron donor. Assay tubes were purged with mixed gas and sealed prior to the addition of $1 \mathrm{ml}$ of standardized cells followed by horizontal incubation at $30^{\circ} \mathrm{C}$ with slow gyratory shaking (25 r.p.m.). At multiple time points, samples were collected in an anoxic atmosphere and analysed for specific reduction. In the $\mathrm{U}(\mathrm{VI})$ reduction assays, soluble $\mathrm{U}(\mathrm{VI})$ remaining in filtrates $(<0.2 \mu \mathrm{m}$ pore size $)$ from all samples was analysed at multiple time points using a kinetic phosphorescence analyser (KPA-10; Chemchek Instruments, Richland, WA) as previously described (Brina and Miller, 1992). Samples generated in experiments with $\mathrm{Si}-\mathrm{HFO}$ or $\mathrm{Fe}(\mathrm{III})-\mathrm{NTA}$ were extracted overnight with $0.5 \mathrm{~N} \mathrm{HCl}$ before determining the $\mathrm{Fe}$ (II) concentration at $562 \mathrm{~nm}$ using the ferrozine assay (Fredrickson et al., 1998). The reduction of insoluble brown $\mathrm{MnO}_{2}$ was monitored by reduction to soluble $\mathrm{Mn}$ (II), which is colourless. $\mathrm{Co}(\mathrm{III})$ or $\mathrm{V}(\mathrm{V})$ reduction was detected by a clearing of the pink colour or the formation of a dark green precipitate in the assay tubes respectively.

\section{Transmission electron microscopy (TEM)}

Resting cells were prepared as described above and incubated with $250 \mu \mathrm{M}$ ammonium pertechnetate and $10 \mathrm{ml}$ of 
$\mathrm{H}_{2}$ for all localization studies. Cells were fixed, embedded and sectioned using anoxic techniques (Marshall et al., 2006). Ultra thin sections were examined at $200 \mathrm{kV}$ using a JEOL 2010 high-resolution TEM equipped with $\mathrm{LaB}_{6}$ filament with a resolution of $1.9 \AA$ coupled with electron dispersive spectroscopy (EDS) (EDS, Oxford). Images and selected area diffraction (SAED) patterns were digitally collected and analysed using DigitalMicrograph software (Gatan, Pleasanton, CA).

\section{Reductase activity of recombinant cytochromes}

The recombinant $c$-type cytochromes, $\mathrm{Mtr} C$ and $\mathrm{OmcA}$, were expressed and purified as described previously (Shi et al., 2006). Proteins were prepared at a concentration of $5.5 \mu \mathrm{M}$ (55 $\mu \mathrm{M}$ haem) in buffer containing $50 \mathrm{mM} \mathrm{N}$-(2-hydroxyethyl)piperazine- $N$-2-ethanesulfonic acid (HEPES) buffer (pH 7.5), $100 \mathrm{mM} \mathrm{NaCl}, 10 \%$ glycerol and $0.5 \%(\mathrm{w} / \mathrm{v})$ 3-[(3-cholamidopropyl)dimethylammonio]-1-propanesulfonate (CHAPS) and purged with $\mathrm{O}_{2}$-free $\mathrm{N}_{2}$ gas for $2 \mathrm{~h}$. A $1.57 \mathrm{mM}$ $\mathrm{Tc}(\mathrm{VIII})$ stock in water was prepared and degassed in similar manner. The reaction of recombinant cytochrome (MtrC or OmcA), which was reduced by titrating with sodium dithionite, with $\mathrm{Tc}(\mathrm{VII})$ was initiated by the addition of $0.45 \mathrm{ml}$ of cytochrome with $0.05 \mathrm{ml}$ of $\mathrm{Tc}(\mathrm{VII})$ stock in an anoxic atmosphere $\left(<0.1\right.$ p.p.m. $\mathrm{O}_{2}$ ). The reaction was mixed by gentile inversion and the oxidation of haem immediately monitored using a Cary 500 Scan UV-Vis-NIR spectrophotometer (Varian, Palo Alto, CA) at $\lambda_{540-560}$ every $\sim 30 \mathrm{~s}$ until complete. Similar reaction containing $0.05 \mathrm{ml}$ of anoxic water without $\mathrm{Tc}(\mathrm{VII})$ was also monitored. The reaction between reduced cytochrome and $\mathrm{Tc}(\mathrm{VII})$ was analysed using protocols detailed by Dobbin and colleagues (1999).

\section{Statistical analysis}

Radionuclide and metal reduction curves were compared using non-parametric procedures, specifically the Wilcoxon signed-rank test. These tests were conducted using Systat 10 (SPSS, Chicago, IL) and were considered significant at $P<0.01$; specific values of $P$ are reported where relevant.

\section{Accession numbers}

The GenBank (http://www.ncbi.nlm.nih.gov/GenBank) accession numbers for the protein sequences described in this article are HydA (gil24375408, HyaB (gil24373658), CymA (gil24376064), MtrC (gil24373344), OmcA (gil24373345), CcmC (gil24371859) and MenD (gil24376046).

\section{Acknowledgements}

This work was supported by the Environmental Remediation Sciences Program (ERSP) and Genomics:Genomes to Life Programs, Office of Biological and Environmental Research (OBER) and the US DOE. A portion of the research was performed at the W.R. Wiley Environmental Molecular Sciences Laboratory (EMSL), a national scientific user facility sponsored by OBER and located at Pacific Northwest National Laboratory (PNNL). Battelle Memorial Institute operates PNNL for the DOE under contract DE-AC05-76RL01830. We would also like to thank Ray Wildung for his careful review of the manuscript and Sonia Enloe for her assistance in the preparation and submission of the manuscript.

\section{References}

Beliaev, A.S., and Saffarini, D.A. (1998) Shewanella putrefaciens $m$ trB encodes an outer membrane protein required for $\mathrm{Fe}(\mathrm{III})$ and $\mathrm{Mn}(\mathrm{IV})$ reduction. J Bacteriol 180: 62926297.

Beliaev, A.S., Saffarini, D.A., McLaughlin, J.L., and Hunnicutt, D. (2001) MtrC, an outer membrane decahaem $c$ cytochrome required for metal reduction in Shewanella putrefaciens MR-1. Mol Microbiol 39: 722-730.

Beliaev, A.S., Klingeman, D.M., Klappenbach, J.A., Wu, L., Romine, M.F., Tiedje, J.M., et al. (2005) Global transcriptome analysis of Shewanella oneidensis MR-1 exposed to different terminal electron acceptors. J Bacteriol 187: 7138-7145.

Bencheikh-Latmani, R., Williams, S.M., Haucke, L., Criddle, C.S., Wu, L., Zhou, J., and Tebo, B.M. (2005) Global transcriptional profiling of Shewanella oneidensis MR-1 during $\mathrm{Cr}(\mathrm{VI})$ and $\mathrm{U}(\mathrm{VI})$ reduction. Appl Environ Microbiol 71: 7453-7460.

Blomfield, I.C., Vaughn, V., Rest, R.F., and Eisenstein, B.I. (1991) Allelic exchange in Escherichia coli using the BacilIus subtilis sacB gene and a temperature-sensitive pSC101 replicon. Mol Microbiol 5: 1447-1457.

Bouhenni, R., Gehrke, A., and Saffarini, D. (2005) Identification of genes involved in cytochrome $c$ biogenesis in Shewanella oneidensis, using a modified mariner transposon. Appl Environ Microbiol 71: 4935-4937.

Brina, R., and Miller, A.G. (1992) Direct detection of trace levels of uranium by laser-induced kinetic phosphorimetry. Anal Chem 64: 1413-1418.

Carpentier, W., Sandra, K., De Smet, I., Brige, A., De Smet, L., and Van Beeumen, J. (2003) Microbial reduction and precipitation of vanadium by Shewanella oneidensis. Appl Environ Microbiol 69: 3636-3639.

De Luca, G., de Philip, P., Dermoun, Z., Rousset, M., and Vermeglio, A. (2001) Reduction of technetium(VII) by Desulfovibrio fructosovorans is mediated by the nickel-iron hydrogenase. Appl Environ Microbiol 67: 4583-4587.

Dehio, C., and Meyer, M. (1997) Maintenance of broad-hostrange incompatibility group $P$ and group $Q$ plasmids and transposition of Tn5 in Bartonella henselae following conjugal plasmid transfer from Escherichia coli. J Bacteriol 179: 538-540.

Dobbin, P.S., Butt, J.N., Powell, A.K., Reid, G.A., and Richardson, D.J. (1999) Characterization of a flavocytochrome that is induced during the anaerobic respiration of $\mathrm{Fe}^{3+}$ by Shewanella frigidimarina NCIMB400. Biochem J 342: 439448.

Fredrickson, J.K., Zachara, J.M., Kennedy, D.W., Dong, H., Onstott, T.C., Hinman, N.W., and Li, S.W. (1998) Biogenic iron mineralization accompanying the dissimilatory reduction of hydrous ferric oxide by a groundwater bacterium. Geochim Cosmochim Acta 62: 3239-3257. 
Fredrickson, J.K., Kostandarithes, H.M., Li, S.W., Plymale, A.E., and Daly, M.J. (2000) Reduction of Fe(III), Cr(VI), $\mathrm{U}(\mathrm{VI})$, and $\mathrm{Tc}(\mathrm{VII})$ by Deinococcus radiodurans $\mathrm{R} 1$. Appl Environ Microbiol 66: 2006-2011.

Fredrickson, J.K., Zachara, J.M., Kennedy, D.W., Kukkadapu, R.K., McKinley, J.P., Heald, S.M., et al. (2004) Reduction of $\mathrm{TcO}_{4}^{-}$by sediment-associated biogenic $\mathrm{Fe}(\mathrm{II})$. Geochim Cosmochim Acta 68: 3171-3187.

Ghirardi, M.L., King, P.W., Posewitz, M.C., Maness, P.C., Fedorov, A., Kim, K., et al., (2005) Approaches to developing biological $\mathrm{H}_{2}$-photoproducing organisms and processes. Biochem Soc Trans 33: 70-72.

Guillaumont, R., Fanghänel, T., Fuger, J., Grenthe, I., Neck, V., Palmer, D.A., and Rand, M.H. (2003) Update on the Chemical Thermodynamics of Uranium, Neptunium, Plutonium, Americium and Technetium. Amsterdam, The Netherlands: Elsevier Science and Technology Books.

Hanahan, D. (1983) Studies on transformation of Escherichia coli with plasmids. J Mol Biol 166: 557-580.

Hanahan, D. (1985) Techniques for transformation in E. coli. In DNA Cloning: A Practical Approach. Glover, D.M. (ed.). Washington, DC, USA: IRL Press, pp. 109-135.

Heidelberg, J.F., Paulsen, I.T., Nelson, K.E., Gaidos, E.J., Nelson, W.C., Read, T.D., et al. (2002) Genome sequence of the dissimilatory metal iron-reducing bacterium Shewanella oneidensis. Nat Biotechnol 20: 1118-1123.

Horner, D.S., Foster, P.G., and Embley, T.M. (2000) Iron hydrogenases and the evolution of anaerobic eukaryotes. Mol Biol Evol 17: 1695-1709.

Kukkadapu, R.K., Zachara, J.M., Fredrickson, J.K., and Kennedy, D.W. (2004) Biotransformation of two-line silicaferrihydrite by a dissimilatory $\mathrm{Fe}$ (III)-reducing bacterium: formation of carbonate green rust in the presence of phosphate. Geochim Cosmochim Acta 68: 2799-2814.

Link, A.J., Phillips, D., and Church, G.M. (1997) Methods for generating precise deletions and insertions in the genome of wild-type Escherichia coli: application to open reading frame characterization. J Bacteriol 179: 6228-6237.

Liu, C., Gorby, Y.A., Zachara, J.M., Fredrickson, J.K., and Brown, C.F. (2002) Reduction kinetics of Fe(III), Co(III), $\mathrm{U}(\mathrm{VI}), \mathrm{Cr}(\mathrm{VI})$, and $\mathrm{Tc}(\mathrm{VII})$ in cultures of dissimilatory metalreducing bacteria. Biotechnol Bioeng 80: 637-649.

Lloyd, J.R., and Macaskie, L.E. (1996) A novel phosphorlmager-based technique for monitoring the microbial reduction of technetium. Appl Environ Microbiol 62: 578-582.

Lloyd, J.R., and Macaskie, L.E. (1997) Microbially-mediated reduction and removal of technetium from solution. Res Microbiol 148: 530-532.

Lloyd, J.R., Ridley, J., Khizniak, T., Lyalikova, N.N., and Macaskie, L.E. (1999a) Reduction of technetium by Desulfovibrio desulfuricans: biocatalyst characterization and use in a flowthrough bioreactor. Appl Environ Microbiol 65: 2691-2696.

Lloyd, J.R., Thomas, G.H., Finlay, J.A., Cole, J.A., and Macaskie, L.E. (1999b) Microbial reduction of technetium by Escherichia coli and Desulfovibrio desulfuricans: enhancement via the use of high-activity strains and effect of process parameters. Biotechnol Bioeng 66: 122130.

Lloyd, J.R., Sole, V.A., Van Praagh, C.V., and Lovley, D.R.
(2000) Direct and Fe(II)-mediated reduction of technetium by $\mathrm{Fe}(\mathrm{III})-r e d u c i n g$ bacteria. Appl Environ Microbiol 66: 3743-3749.

de Lorenzo, V., Herrero, M., Jakubzik, U., and Timmis, K.N. (1990) Mini-Tn5 transposon derivatives for insertion mutagenesis, promoter probing, and chromosomal insertion of cloned DNA in Gram-negative eubacteria. $J$ Bacteriol 172: 6568-6572.

Lovley, D.R., Holmes, D.E., and Nevin, K.P. (2004) Dissimilatory $\mathrm{Fe}(\mathrm{III})$ and $\mathrm{Mn}(\mathrm{IV})$ reduction. Adv Microb Physiol 49: 219-286.

Marshall, M.J., Beliaev, A.S., Dohnalkova, A.C., Kennedy, D.W., Shi, L., Wang, Z., et al. (2006) c-Type cytochromedependent formation of U(IV) nanoparticles by Shewanella oneidensis. PLoS Biol 4: e268.

Meshulam-Simon, G., Behrens, S., Choo, A.D., and Spormann, A.M. (2007) Hydrogen metabolism in Shewanella oneidensis MR-1. Appl Environ Microbiol 73: 1153-1165.

Meyer, T.E., Tsapin, A.I., Vandenberghe, I., de Smet, L., Frishman, D., Nealson, K.H., et al. (2004) Identification of 42 possible cytochrome $c$ genes in the Shewanella oneidensis genome and characterization of six soluble cytochromes. OMICS 8: 57-77.

Myers, C.R., and Myers, J.M. (1992) Localization of cytochromes to the outer membrane of anaerobically grown Shewanella putrefaciens MR-1. J Bacteriol 174: 34293438.

Myers, C.R., and Myers, J.M. (2003a) Cell surface exposure of the outer membrane cytochromes of Shewanella oneidensis MR-1. Lett Appl Microbiol 37: 254-258.

Myers, C.R., and Nealson, K.H. (1988) Bacterial manganese reduction and growth with manganese oxide as the sole electron acceptor. Science 240: 1319-1321.

Myers, C.R., and Nealson, K.H. (1990) Respiration-linked proton translocation coupled to anaerobic reduction of manganese(IV) and iron(III) in Shewanella putrefaciens MR-1. J Bacteriol 172: 6232-6238.

Myers, J.M., and Myers, C.R. (1998) Isolation and sequence of $o m c A$, a gene encoding a decaheme outer membrane cytochrome $c$ of Shewanella putrefaciens MR-1, and detection of omcA homologs in other strains of S. putrefaciens. Biochim Biophys Acta 1373: 237-251.

Myers, J.M., and Myers, C.R. (2000) Role of the tetraheme cytochrome CymA in anaerobic electron transport in cells of Shewanella putrefaciens MR-1 with normal levels of menaquinone. J Bacteriol 182: 67-75.

Myers, J.M., and Myers, C.R. (2001) Role for outer membrane cytochromes OmcA and OmcB of Shewanella putrefaciens MR-1 in reduction of manganese dioxide. Appl Environ Microbiol 67: 260-269.

Myers, J.M., and Myers, C.R. (2003b) Overlapping role of the outer membrane cytochromes of Shewanella oneidensis MR-1 in the reduction of manganese(IV) oxide. Lett Appl Microbiol 37: 21-25.

Nealson, K.H., and Saffarini, D. (1994) Iron and manganese in anaerobic respiration: environmental significance, physiology, and regulation. Annu Rev Microbiol 48: 311-343.

Payne, A.N., and DiChristina, T.J. (2006) A rapid mutant screening technique for detection of technetium [Tc(VII)] 
reduction-deficient mutants of Shewanella oneidensis MR-1. FEMS Microbiol Lett 259: 282-287.

Peck, H.D. (1993) Bioenergetic strategies of the sulfatereducing bacteria. In The Sulfate-Reducing Bacteria: Contemporary Perspectives. Odom, J.M., and Singleton, R. (eds). New York, USA: Springer-Verlag, pp. 41-76.

Rard, J.A., Rand, M.H., Anderegg, G., and Wanner, H. (1999) Chemical Thermodynamics of Technetium. New York, USA: Elsevier Science and Technology Books.

Riley, R.G., Zachara, J.M., and Wobber, F.J. (1992) Chemical Contaminants on DOE Lands and Selection of Contaminant Mixtures for Subsurface Science Research. Washington, DC, USA: US Department of Energy.

Saffarini, D.A., Blumerman, S.L., and Mansoorabadi, K.J. (2002) Role of menaquinones in Fe(III) reduction by membrane fractions of Shewanella putrefaciens. J Bacteriol 184: 846-848.

Sambrook, J., Fritsch, E.F., and Maniatis, T. (1989) Molecular Cloning: A Laboratory Manual. Cold Spring Harbor, NY, USA: Cold Spring Harbor Laboratory Press.

Shi, L., Chen, B., Wang, Z., Elias, D.A., Mayer, U., Gorby, Y.A., et al. (2006) Isolation of high-affinity functional protein complex between OmcA and MtrC: two outer membrane decaheme $c$-type cytochromes of Shewanella oneidensis MR-1. J Bacteriol 188: 4705-4714.

Teixeira, M., Moura, I., Xavier, A.V., Moura, J.J., LeGall, J., DerVartanian, D.V., et al. (1989) Redox intermediates of Desulfovibrio gigas [NiFe] hydrogenase generated under hydrogen. Mossbauer and EPR characterization of the metal centers. J Biol Chem 264: 16435-16450.

Tribalat, S., and Beydon, J. (1953) Isolement du technetium. Anal Chim Acta 8: 22-28.

Vignais, P.M., and Colbeau, A. (2004) Molecular biology of microbial hydrogenases. Curr Issues Mol Biol 6: 159-188.

Vignais, P.M., Billoud, B., and Meyer, J. (2001) Classification and phylogeny of hydrogenases. FEMS Microbiol Rev 25: 455-501.

Wan, X.F., Verberkmoes, N.C., McCue, L.A., Stanek, D., Connelly, H., Hauser, L.J., et al. (2004) Transcriptomic and proteomic characterization of the Fur modulon in the metalreducing bacterium Shewanella oneidensis. J Bacteriol 186: 8385-8400.

Wigginton, N.S., Rosso, K.M., Lower, B.H., Shi, L., and Hochella, M.F.J. (2007) Electron tunneling properties of outermembrane decaheme cytochromes from Shewanella oneidensis. Geochim Cosmochim Acta 71: 543-555.

Wildung, R.E., Gorby, Y.A., Krupka, K.M., Hess, N.J., Li, S.W., Plymale, A.E., et al. (2000) Effect of electron donor and solution chemistry on products of dissimilatory reduction of technetium by Shewanella putrefaciens. Appl Environ Microbiol 66: 2451-2460.

Xiong, Y., Shi, L., Chen, B., Mayer, M.U., Lower, B.H., Londer, Y., et al. (2006) High-affinity binding and direct electron transfer to solid metals by the Shewanella oneidensis MR-1 outer membrane c-type cytochrome OmcA. J Am Chem Soc 128: 13978-13979.

\section{Supplementary material}

The following supplementary material is available for this article online:

Fig. S1. The effect of TSB-dex pre-growth on the resting-cell $\mathrm{Tc}(\mathrm{VII})$ reduction kinetics by $S$. oneidensis MR-1 cells. The reduction of $100 \mu \mathrm{M} \mathrm{Tc}(\mathrm{VII})$ was determined for MR-1 either by using $10 \mathrm{ml}$ of $\mathrm{H}_{2}$ as the electron donor (MR-1) or by not supplying an electron donor [MR-1 (no donor)].

Fig. S2. The effect of electron donor on metal reduction by S. oneidensis MR-1 and hydrogenase mutant cells. The reduction of several metals was determined using either 10 $\mathrm{mM}$ sodium lactate $(\mathrm{A}, \mathrm{C}, \mathrm{E}$ and $\mathrm{G})$ or $10 \mathrm{ml}$ of $\mathrm{H}_{2}(\mathrm{~B}, \mathrm{D}, \mathrm{F}$ and $\mathrm{H})$ as the sole electron donor in standard reduction assays. $\mathrm{U}(\mathrm{VI})$ reduction kinetics $(250 \mu \mathrm{M})$ was determined for MR-1, single-hydrogenase deletion mutants $\left(\mathrm{HydA}^{-}\right.$or $\left.\mathrm{HyaB}^{-}\right)$and a double-hydrogenase deletion mutant $\left(\mathrm{HydA}^{-} / \mathrm{HyaB}^{-}\right)$( $\mathrm{A}$ and $B)$. The reduction kinetics of $10 \mathrm{mM} \mathrm{HFO}(\mathrm{C}$ and $\mathrm{D})$ or $1.0 \mathrm{mM}$ $\mathrm{Fe}(\mathrm{III})-\mathrm{NTA}$ ( $\mathrm{E}$ and $\mathrm{F}$ ) was determined by quantifying the $0.5 \mathrm{~N} \mathrm{HCl}$ extractable $\mathrm{Fe}(\mathrm{II})$ in solution at all time points. The NiFe hydrogenase deletion mutant pre-induced with thiosulfate incubation $\left[\mathrm{HyaB}^{-}\right.$(thio)] was also tested for reduction of $\mathrm{U}(\mathrm{VI})$ or $\mathrm{Fe}(\mathrm{III})-\mathrm{NTA}$ using $\mathrm{H}_{2}$ as the electron donor (B and $\mathrm{F}$ ). The reduction of $1.0 \mathrm{mM} \mathrm{Co}(\mathrm{III}), 1.0 \mathrm{mM} \mathrm{Mn}(\mathrm{IV})$ or $10 \mathrm{mM}$ $\mathrm{V}(\mathrm{V})$ was determined visually for MR-1 (lanes 1), $\mathrm{HydA}^{-}$ (lanes 2), HyaB- (lanes 3), HydA-/HyaB- (lanes 4), HyaB(thio) (lane 5) and heat-killed MR-1 cells (lanes 6) (G and H). Reduction was recorded as colour change from pink to clear [Co(III) reduction], clearing of the black precipitate [Mn(IV) reduction] or the appearance of a dark green precipitate $[\mathrm{V}(\mathrm{V})$ reduction] relative to non-reducing, heat-killed MR-1 cells. No reduction was observed in our assays when heat-killed, thiosulfate-induced $\mathrm{NiFe}$ hydrogenase mutant cells were assayed (data not shown). Images illustrate the representative data from multiple experiments.

Fig. S3. The complementation of the $\mathrm{H}_{2}$-driven metal reduction-deficient phenotype of the $\mathrm{NiFe}$ hydrogenase mutant cells. The reduction of $250 \mu \mathrm{M} \mathrm{U}(\mathrm{VI})$ or $10 \mu \mathrm{M}$ HFO was determined for NiFe hydrogenase mutant cells containing the complementation plasmid $\left[\mathrm{HyaB}^{-}(+\mathrm{pCR} 4-h y a B)\right]$ and wild-type MR-1 cells using $10 \mathrm{ml}$ of $\mathrm{H}_{2}$ as the electron donor. Fig. S4. The $\mathrm{H}_{2}$-driven $\mathrm{U}(\mathrm{VI})$ reduction kinetics and $\mathrm{UO}_{2}$ nanoparticle localization by $S$. oneidensis MR-1. The reduction of $250 \mu \mathrm{M} \mathrm{U}(\mathrm{VI})$ was determined for MR-1 and a mutant lacking all $c$-type cytochromes $\left(\mathrm{CcmC}^{-}\right)$. The $\mathrm{U}(\mathrm{VI})$ reduction kinetics was determined using $10 \mathrm{ml}$ of $\mathrm{H}_{2}$ as the sole electron donor.

A. Whole mount TEM micrograph prepared from cell suspension of $S$. oneidensis MR-1 incubated with $250 \mu \mathrm{M}$ uranyl acetate and $10 \mathrm{ml}$ of $\mathrm{H}_{2}$ for $24 \mathrm{~h}$.

$B$. The localization of the $\mathrm{UO}_{2}$-EPS is shown in association with intact cells.

Table S1. Electron donor-dependant specific rates of Tc(VII) reduction.

This material is available as part of the online article from http://www.blackwell-synergy.com 


\section{Supporting Information}

Fig. S1. The effect of TSB-dex pre-growth on the resting-cell Tc(VII) reduction kinetics by $S$. oneidensis MR-1 cells. The reduction of $100 \mu \mathrm{M} \mathrm{Tc}$ (VII) was determined for MR-1 either by using $10 \mathrm{ml}$ of $\mathrm{H}_{2}$ as the electron donor (MR-1) or by not supplying an electron donor [MR-1 (no donor)].

Fig. S2. The effect of electron donor on metal reduction by $S$. oneidensis MR-1 and hydrogenase mutant cells. The reduction of several metals was determined using either $10 \mathrm{mM}$ sodium lactate (A, C, E and $\mathrm{G}$ ) or $10 \mathrm{ml}$ of $\mathrm{H}_{2}(\mathrm{~B}, \mathrm{D}, \mathrm{F}$ and $\mathrm{H})$ as the sole electron donor in standard reduction assays. $\mathrm{U}(\mathrm{VI})$ reduction kinetics $(250 \mu \mathrm{M})$ was determined for MR-1, single-hydrogenase deletion mutants $\left(\mathrm{HydA}^{-}\right.$or $\left.\mathrm{HyaB}^{-}\right)$and a double-hydrogenase deletion mutant $\left(\mathrm{HydA}^{-} / \mathrm{HyaB}^{-}\right)$ (A and $\mathrm{B})$. The reduction kinetics of $10 \mathrm{mM}$ HFO (C and D) or $1.0 \mathrm{mM} \mathrm{Fe(III)-NTA} \mathrm{(E} \mathrm{and} \mathrm{F)}$ was determined by quantifying the $0.5 \mathrm{~N} \mathrm{HCl}$ extractable $\mathrm{Fe}(\mathrm{II})$ in solution at all time points. The $\mathrm{NiFe}$ hydrogenase deletion mutant pre-induced with thiosulfate incubation [ $\mathrm{HyaB}^{-}$(thio)] was also tested for reduction of $\mathrm{U}(\mathrm{VI})$ or $\mathrm{Fe}(\mathrm{III})$-NTA using $\mathrm{H}_{2}$ as the electron donor (B and F). The reduction of $1.0 \mathrm{mM} \mathrm{Co}(\mathrm{III}), 1.0 \mathrm{mM} \mathrm{Mn}(\mathrm{IV})$ or $10 \mathrm{mM} \mathrm{V}(\mathrm{V})$ was determined visually for MR1 (lanes 1), Hyd ${ }^{-}$(lanes 2), $\mathrm{HyaB}^{-}$(lanes 3), $\mathrm{HydA}^{-} / \mathrm{HyaB}^{-}$(lanes 4), $\mathrm{HyaB}^{-}$(thio) (lane 5) and heat-killed MR-1 cells (lanes 6) ( $\mathrm{G}$ and $\mathrm{H}$ ). Reduction was recorded as colour change from pink to clear [Co(III) reduction], clearing of the black precipitate [Mn(IV) reduction] or the appearance of a dark green precipitate $[\mathrm{V}(\mathrm{V})$ reduction] relative to non-reducing, heat-killed MR-1 cells. No reduction was observed in our assays when heat-killed, thiosulfate-induced NiFe hydrogenase mutant cells were assayed (data not shown). Images illustrate the representative data from multiple experiments.

Fig. S3. The complementation of the $\mathrm{H}_{2}$-driven metal reduction-deficient phenotype of the $\mathrm{NiFe}$ hydrogenase mutant cells. The reduction of $250 \mu \mathrm{M} \mathrm{U}(\mathrm{VI})$ or $10 \mu \mathrm{M}$ HFO was determined for $\mathrm{NiFe}$ hydrogenase mutant cells containing the complementation plasmid [ $\left.\mathrm{HyaB}^{-}(+\mathrm{pCR} 4-h y a B)\right]$ and wild-type MR-1 cells using $10 \mathrm{ml}$ of $\mathrm{H}_{2}$ as the electron donor.

Fig. S4. The $\mathrm{H}_{2}$-driven $\mathrm{U}(\mathrm{VI})$ reduction kinetics and $\mathrm{UO}_{2}$ nanoparticle localization by $S$. oneidensis MR-1. The reduction of $250 \mu \mathrm{M} \mathrm{U}(\mathrm{VI})$ was determined for MR-1 and a mutant lacking all $c$-type cytochromes $\left(\mathrm{CcmC}^{-}\right)$. The $\mathrm{U}(\mathrm{VI})$ reduction kinetics was determined using 10 $\mathrm{ml}$ of $\mathrm{H}_{2}$ as the sole electron donor. A. Whole mount TEM micrograph prepared from cell suspension of $S$. oneidensis MR-1 incubated with $250 \mu \mathrm{M}$ uranyl acetate and $10 \mathrm{ml}$ of $\mathrm{H}_{2}$ for 24 $\mathrm{h}$. B. The localization of the $\mathrm{UO}_{2}$-EPS is shown in association with intact cells.

Table S1. Electron donor-dependant specific rates of Tc(VII) reduction. 


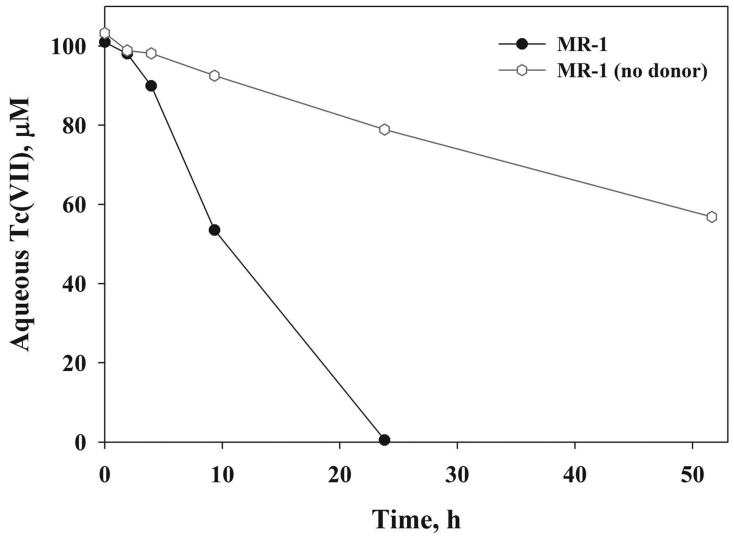


A

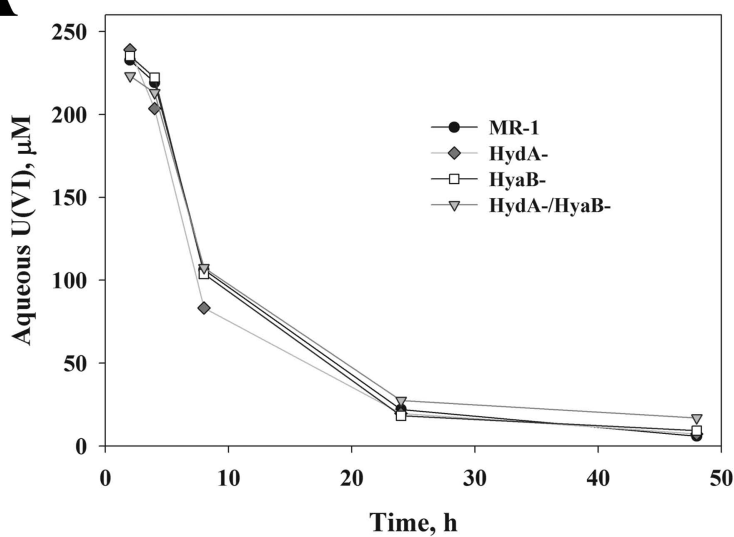

C

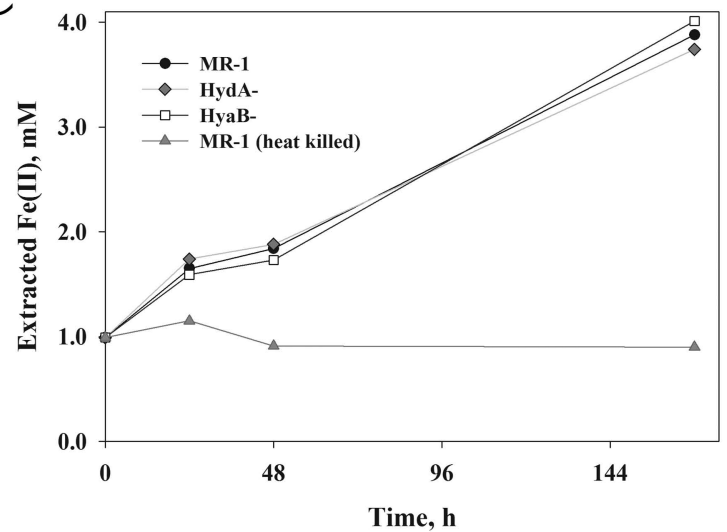

$\mathbf{E}$

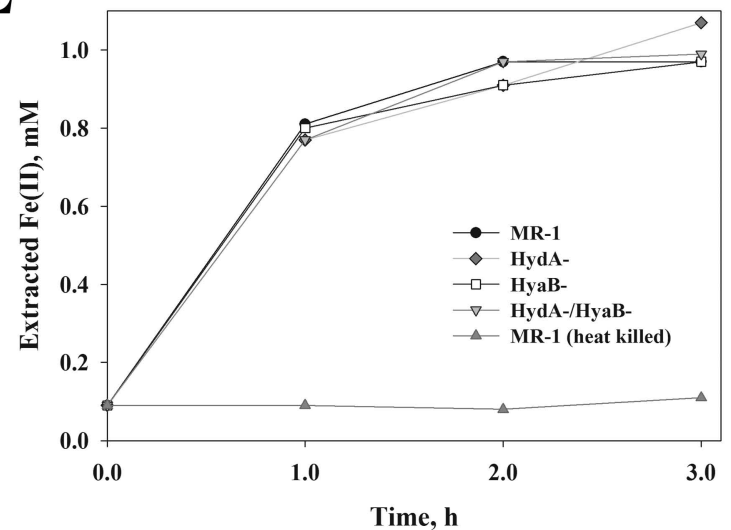

G

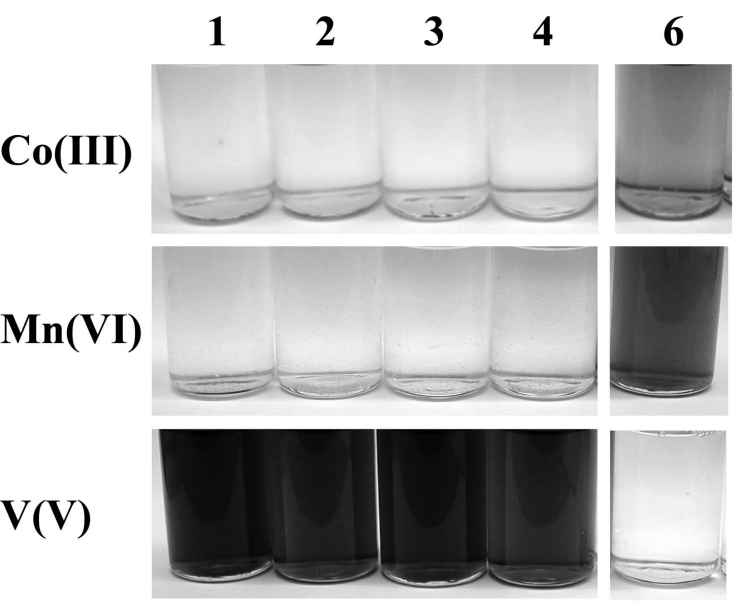

B

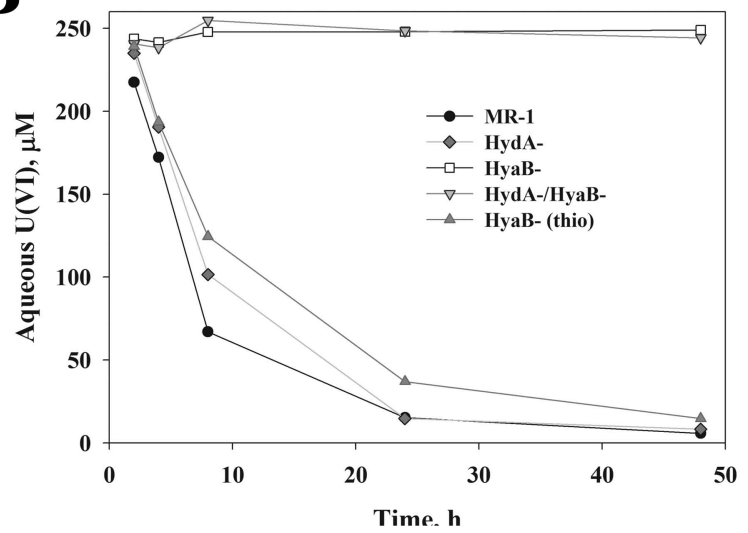

D

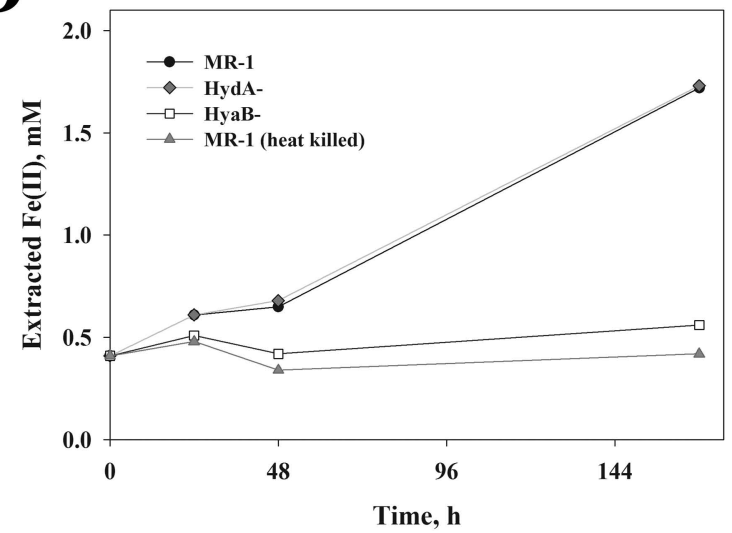

F

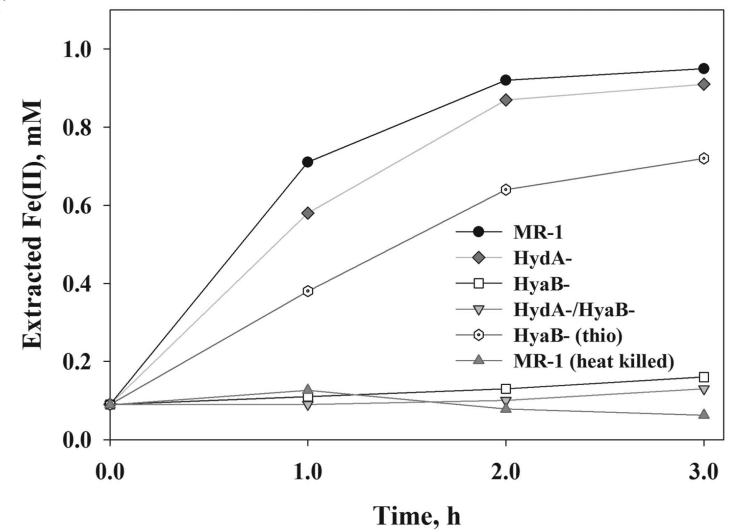

H

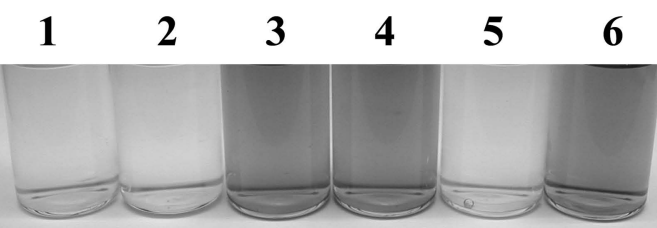

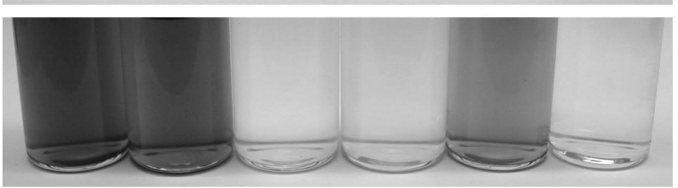




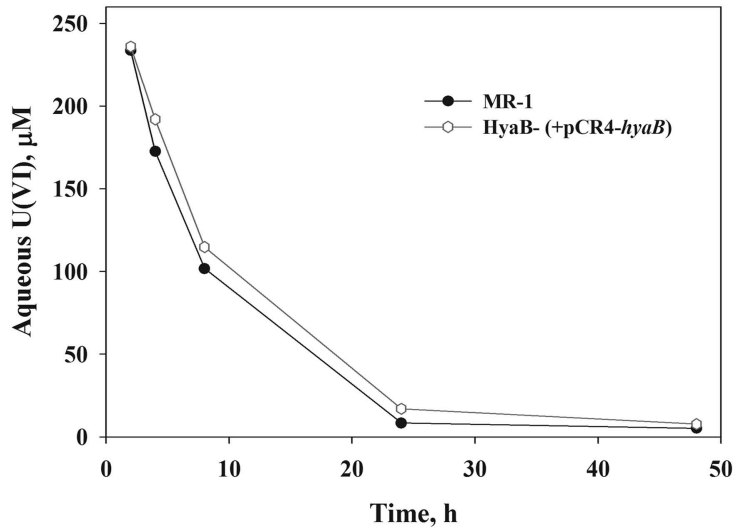

B

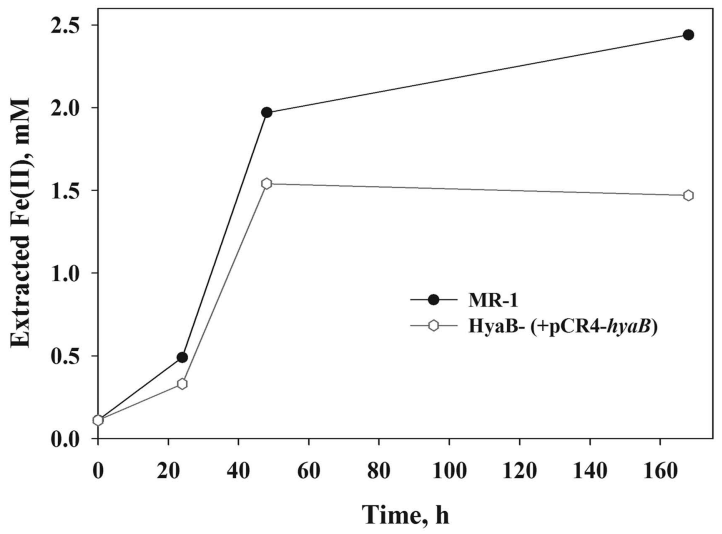


A

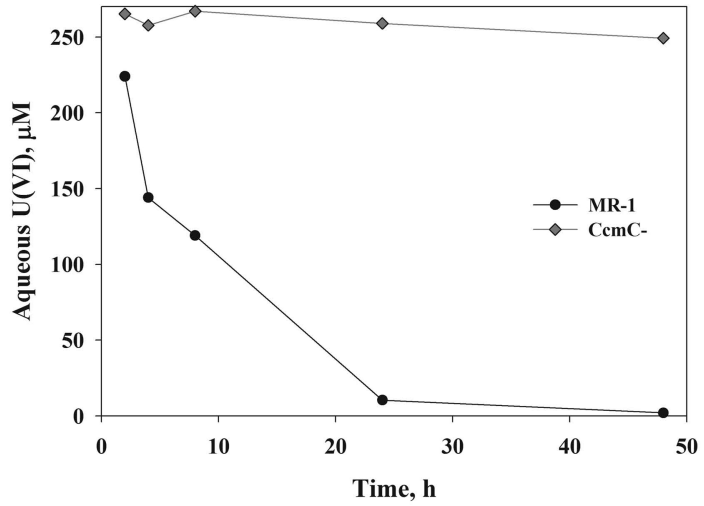

B

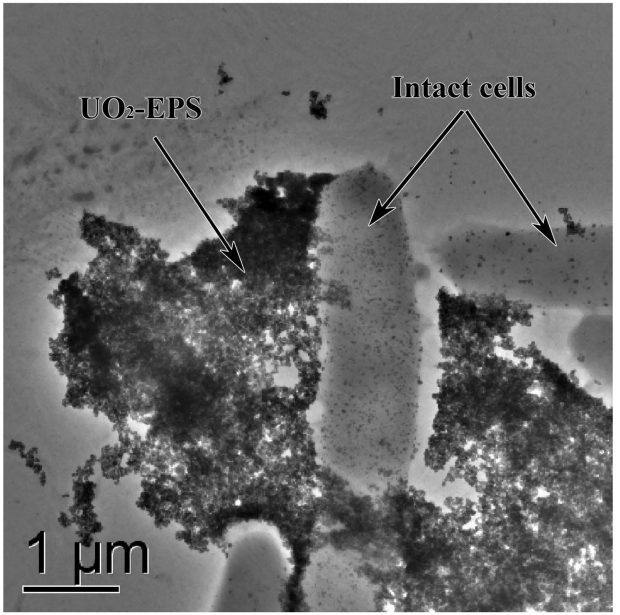




\section{Table S1.}

Electron donor-dependant specific rates of Tc(VII) reduction.

\begin{tabular}{lll}
\hline & \multicolumn{2}{c}{ Specific rate $^{a b}$} \\
\cline { 2 - 3 } Strain & \multicolumn{1}{c}{$\mathrm{H}_{2}$} & \multicolumn{1}{c}{ Lactate } \\
\hline MR-1 & $39.56 \pm 1.40$ & $4.17 \pm 0.60$ \\
$\mathrm{HydA}^{-}$ & $38.08 \pm 2.55$ & nd \\
$\mathrm{HyaB}^{-}$ & $5.24 \pm 1.51$ & $2.58 \pm 0.78$ \\
$\mathrm{HydA}^{-} / \mathrm{HyaB}^{-}$ & $5.48 \pm 1.73$ & nd \\
$\mathrm{MtrC}^{-} / \mathrm{OmcA}^{-}$ & $42.72 \pm 3.56$ & $0.76 \pm 0.80$ \\
\hline
\end{tabular}

${ }^{a}$ Specific rate is reported in umole Tc(VII) reduced g total protein ${ }^{-1} \mathrm{~h}^{-1}$ at $30^{\circ} \mathrm{C}$.

${ }^{b}$ Initial specific rate was determined for the first 9 hours of Tc(VII) reduction with $\mathrm{H}_{2}$ or the first 48 hours of Tc(VII) reduction with lactate.

Data represents the mean and standard deviation from representative experiments $(n=4)$. nd, not determined 